\title{
Análise de proveniência dos arenitos conglomeráticos do Grupo Guaritas (RS): implicações para o paleoclima e a paleogeografia da sub-bacia Camaquã Central no Eocambriano
}

\author{
Provenance analysis of the Guaritas Group (RS) conglomeratic sandstones: implications \\ for the paleoclimate and paleogeography of the Eocambrian Central Camaquã sub-basin
}

\author{
Lucas Padoan de Sá Godinho¹, Renato Paes de Almeida², André Marconato, \\ Mauricio Guerreiro Martinho dos Santos ${ }^{1}$, Antonio Romalino Santos Fragoso-Cesar ${ }^{2}$ \\ 'Programa de Geoquímica e Geotectônica, Instituto de Geociências, Universidade de São Paulo - USP, Rua do Lago 562, \\ CEP 05508-080, São Paulo, SP, BR (lucaspsgodinho@gmail.com; andre.marconato@usp.br; mauricioguerreiro@yahoo.com) \\ 2Departamento de Geologia Sedimentar e Ambiental, Instituto de Geociências, Universidade de São Paulo - USP, São Paulo, \\ SP, BR (rpalmeid@usp.br; romalino@usp.br)
}

Recebido em 09 de abril de 2012; aceito em 08 de março de 2013

\begin{abstract}
Resumo
O Supergrupo Camaquã, localizado na região centro-sul do Rio Grande do Sul, Brasil, constitui uma bacia sedimentar pós-orogênica do tipo rift, cuja deposição ocorreu em ambiente continental entre o Ediacarano e o Eocambriano. O topo da sucessão do Supergrupo Camaquã é representado pelo Grupo Guaritas, uma unidade formada por depósitos fluviais, eólicos e de leques aluviais que abriga importantes registros da sedimentação logo após o final das orogêneses neoproterozoicas que deram origem ao supercontinente Gondwana. O objetivo do presente trabalho foi aplicar a análise de proveniência sedimentar em arenitos conglomeráticos e conglomerados do Grupo Guaritas, a fim de explorar a história da evolução tectônica e climática dessa unidade. Com base nos dados composicionais de seixos, foram reconhecidas duas áreas fonte principais para os depósitos dessa unidade, uma mais distal e situada a norte, relacionada a um sistema de rio tronco paralelo ao eixo principal da bacia, e outra mais proximal e situada a leste, relacionada a sistemas fluviais transversais e de leques aluviais da borda da bacia. O confronto dos dados de proveniência com estudos anteriores de fácies e paleocorrentes sugere que, durante toda a evolução da borda leste da bacia, houve um mesmo sistema fluvial transversal, cuja área de captação sofreu reduções significativas devido à reativação da falha da borda leste durante a deposição das formações Varzinha e Pedra Pintada. Na Formação Serra do Apertado, unidade de topo do Grupo Guaritas, foi verificada uma alta correlação entre a variação dos seixos de composição quartzosa e não quartzosa, e isso foi atribuído a variações entre climas mais úmidos e mais áridos.
\end{abstract}

Palavras-chave: Grupo Guaritas; Análise de proveniência; Seixos; Paleogeografia; Paleoclima.

\begin{abstract}
The Camaquã Supergroup, located in the central-south region of Rio Grande do Sul, Brazil, constitutes a rift-type post-orogenic sedimentary basin, whose deposition occurred in a continental environment between the Ediacaran and the Eocambrian. The upper succession of the Camaquã Supergroup is represented by the Guaritas Group, a unit formed by fluvial, eolian and alluvial fan deposits that keeps important records of the sedimentation right after the end of the neoproterozoic orogenesis that gave rise to the Gondwana supercontinent. The objective of the present work was to apply sedimentary provenance analysis in conglomeratic arenites and conglomerates of the Guaritas Group, in order to explore the climatic and tectonic evolution history of this unit. Based on the pebble compositional data, two main source areas were recognized for the deposits of this unit, a more distal one located to the north, related with a trunk river system parallel to the basin main axis, and a more proximal one located to the east, related to transversal fluvial systems and alluvial fans at the border of the basin. The comparison of the provenance data with previous studies on facies and paleocurrents suggests that, during the entire evolution of the east border of the basin, there was a same transversal fluvial system, whose catchment area suffered significative reductions due to the reactivation of the east border fault during the deposition of the Varzinha and Pedra Pintada Formations. The Serra do Apertado Formation, the upper unit of Guaritas Group, shows a high correlation between the variation of quartzose and non quartzose pebbles composition, and it was attributed to a variation between more humid and more arid climatic conditions.
\end{abstract}

Keywords: Guaritas Group; Provenance analysis; Pebbles; Paleogeography; Paleoclimate. 


\section{INTRODUÇÃO}

O Grupo Guaritas é uma unidade sedimentar formada em uma bacia do tipo rift durante o Eocambriano, que ocorre sobre as rochas do embasamento do Rio Grande do Sul (Fragoso-Cesar, 1991), sendo composta por depósitos continentais de ambientes de rios dominados por carga de fundo, rios dominados por carga mista, campos de dunas eólicas e leques aluviais (Paim, 1994; Almeida, 2005). Dessa forma, tais depósitos abrigam um registro muito raro e fértil para estudos das relações entre sedimentação e variações tectônicas e climáticas num período pré-vegetação terrestre (Tisgaard e Øxnevad, 1998; Long, 2006; Davies e Gibling, 2010).

A análise de proveniência sedimentar é um método que vem sendo muito utilizado no estudo do comportamento tectônico das áreas fonte, assim como das variações climáticas e geomorfológicas que participam do contexto da sedimentação, constituindo uma importante ferramenta na reconstituição de paleoambientes deposicionais (e.g. Graham et al., 1986; Dürr, 1996; Jones, 2000). Até hoje, foram realizados poucos estudos sistemáticos sobre a composição dos depósitos do Grupo Guaritas, em especial de sua unidade de topo recém-descoberta, a Formação Serra do Apertado (Almeida, 2005), de forma que mais investigações científicas nesse âmbito podem contribuir para uma aproximação dos fenômenos tectônicos e climáticos que participaram de sua evolução.

No presente estudo, foi realizada a análise de proveniência nas cinco unidades pertencentes ao Grupo Guaritas, sendo elas, da base para o topo, Formações Guarda Velha, Varzinha, Pedra Pintada, Pedra das Torrinhas (correlata lateralmente às duas últimas) e Serra do Apertado (sensu Almeida, 2005), tendo em vista dois objetivos principais: (i) comparar as características composicionais das unidades acima citadas e testar a eficácia do método utilizado para o estudo de variações tectônicas e climáticas; (ii) detalhar os estudos de proveniência e paleocorrentes da recém-descoberta Formação Serra do Apertado.

\section{MÉTODOS}

\section{Análise de proveniência macroscópica}

A análise de proveniência no estudo de rochas sedimentares é utilizada para reconstituir a composição das rochas parentais que serviram como fonte para o sedimento (Weltje e von Eynatten, 2004). No presente estudo, a análise de proveniência macroscópica foi realizada por meio da contagem de seixos em arenitos conglomeráticos e conglomerados, abundantes na área de estudo. A metodologia utilizada baseia-se nas propostas de Dürr (1994) e Marconato (2010).

Para cada sítio de observação, foram contados todos os clastos maiores que $0,5 \mathrm{~cm}$, como seixos, calhaus e matacões, contidos em uma ou mais áreas retangulares, totalizando aproximadamente 300 clastos por estação de medida. Trinta e três estações foram analisadas, com um total de 10.200 clastos contados. Apesar de a proposta original de Dürr (1994) sugerir que a contribuição de cada litotipo para o depósito seja expressa em grandeza de volume, no presente estudo essa variável foi expressa em grandeza de área, pois os afloramentos não permitem uma exposição tridimensional dos seixos. Segundo Marconato (2010), a estimativa da contribuição dos litotipos em área, similarmente à estimativa por volume, minimiza os possíveis erros advindos da simples contagem de frequência, que, por sua vez, não considera uma possível dependência entre litotipo e tamanho de fragmento. A estimativa por área pode ser feita atribuindo-se um parâmetro de forma para o seixo e medindo-se seus eixos maior e menor (Marconato, 2010).

\section{Análise estatística dos dados de proveniência}

Os dados de composição de seixos foram tratados por meio de análise estatística multivariada, pois esta permite facilitar a interpretação acerca dos dados quando há uma grande quantidade de variáveis atribuídas a cada unidade de observação (Davis, 1986). Os dados foram tratados como composicionais, ou seja, todas as variáveis de uma mesma unidade de observação estão inter-relacionadas, e a variação em uma delas acarreta obrigatoriamente a variação das demais, sendo que a soma de todas elas chegam a uma dada constante, como, por exemplo, 100 - se forem expressas em porcentagem - , ou 1, se forem expressas como partes por unidade (Pawlowsky-Glahn e Egozcue, 2006).

Uma vez que os dados composicionais não podem ser diretamente tratados por meio de métodos estatísticos convencionais, devido às suas propriedades intrínsecas, utilizou-se a transformação logarítmica (Aitchison, 1986; PawlowskyGlahn e Egozcue, 2006), a fim de representá-los como dados independentes de vetores e que podem ser aplicados à analise multivariada de dados. A técnica de transformação adotada foi a razão logarítmica centrada (clr) por se aplicar melhor à análise multivariada de dados (Pawlowsky-Glahn e Egozcue, 2006). Anteriormente ao procedimento de transformação logarítmica acima mencionado, os valores iguais a zero, os quais representam litotipos que possivelmente não ocorrem na unidade de observação ou não foram detectados pelo método de amostragem utilizado, foram substituídos pelos valores do mínimo erro amostral relacionado à sua ocorrência, segundo o método introduzido por Marconato (2010).

\section{GEOLOGIA REGIONAL}

O Grupo Guaritas é uma unidade sedimentar com mais de $1.500 \mathrm{~m}$ de espessura (Almeida, 2005), que ocorre na 
região sul do Estado do Rio Grande do Sul, com depósitos siliciclásticos de ambiente continental que se formaram no Eocambriano, em bacia do tipo rift (Fragoso-Cesar et al., 2003; Paim e Scherer, 2007; Almeida et al., 2009). Constitui a unidade de topo do Supergrupo Camaquã, que, por sua vez, apresenta ao todo mais de $10.000 \mathrm{~m}$ de espessura e é subdividida em 5 unidades principais, sendo elas, da base para o topo: Grupo Maricá (depósitos fluviais e de mar raso continental), Grupo Bom Jardim (depósitos fluviais intercalados com rochas vulcânicas), Formação
Acampamento Velho (rochas vulcânicas e vulcanoclásticas ácidas e básicas), Grupo Santa Bárbara (depósitos fluviais e de leques aluviais) e Grupo Guaritas (depósitos fluviais, eólicos e de leques aluviais) (Ribeiro et al., 1966; FragosoCesar et al., 2000; Almeida, 2005; Janikian et al., 2008).

A área onde aflora o Grupo Guaritas possui formato alongado, com cerca de $30 \mathrm{~km}$ de largura e mais de $100 \mathrm{~km}$ de comprimento, e seu eixo longitudinal é orientado segundo a direção NE-SW (Figura 1). Segundo estudos de mapeamento de detalhe realizados por Almeida (2005), o

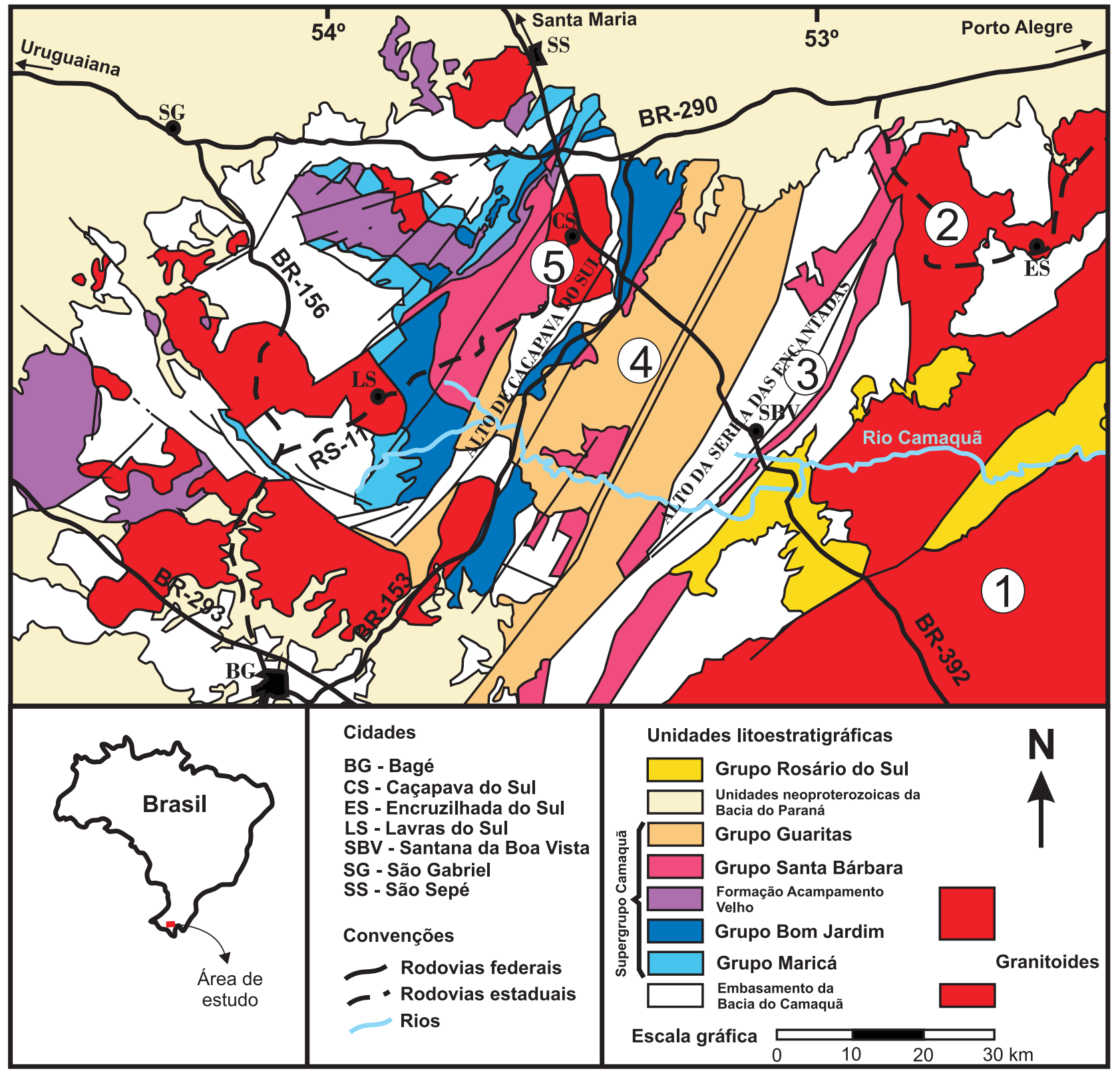

Figura 1. Mapa geológico da Bacia do Camaquã e áreas adjacentes. Extraído de Almeida (2005). 1: Batólito Pelotas; 2: Batólito Encruzilhada do Sul; 3: Serra das Encantadas, parte integrante do Cinturão Dom Feliciano; 4: Grupo Guaritas; 5: Alto de Caçapava do Sul, parte integrante do Cinturão Ribeira. 
Grupo Guaritas se subdivide em cinco unidades (Figura 2). Da base para o topo, tais unidades são as formações Guarda Velha (ambiente fluvial dominado por carga de fundo), Varzinha (ambiente fluvial dominado por carga mista), Pedra Pintada (ambiente eólico com interdunas), Pedra das Torrinhas (ambiente de leques aluviais, lateralmente correlato às Formações Varzinha e Pedra Pintada) e Serra do Apertado (ambiente fluvial dominado por carga de fundo) (Almeida, 2005). Dentro do Grupo Guaritas, ocorrem também intrusões de magmas básicos a intermediários, denominados Suíte Intrusiva Rodeio Velho (Almeida, 2005; Paim e Scherer, 2007).

Durante a história de deposição do Supergrupo Camaquã, ocorreram eventos tectônicos que culminaram no soerguimento de altos estruturais internos à bacia, dividindo-o em três Sub-Bacias, denominadas Camaquã Ocidental, Camaquã Central e Camaquã Oriental (Fragoso-Cesar et al., 2000; Almeida, 2005). A Sub-Bacia Camaquã Central, onde se encontra o Grupo Guaritas, é delimitada tanto a leste como a oeste por zonas de falhas de alto ângulo e direção NNE-SSW, sendo elas, respectivamente, a Zona de falhas das Encantadas e a Falha da Angélica (Almeida, 2005). No contato a leste, situa-se o alto da Serra das Encantadas, com rochas do Cinturão Dom Feliciano, e a oeste, ocorre o Alto de Caçapava do Sul, com rochas do Terreno Rio Vacacaí e intrusivas mais jovens (Fragoso-Cesar, 1991). Ao norte, a Sub-Bacia Camaquã Central apresenta contato com rochas Paleozoicas da Bacia do Paraná, definido por uma discordância erosiva; ao sul, o contato é tectônico, com rochas do Cinturão Dom Feliciano e Terreno Rio Vacacaí (Almeida, 2005).
A seguir, será apresentado um breve panorama das unidades geológicas que afloram adjacentes ao Supergrupo Camaquã, para que possa servir de embasamento para as discussões posteriores a respeito dos resultados obtidos da proveniência sedimentar.

\section{O Cinturão Dom Feliciano}

O Cinturão Dom Feliciano é uma faixa de dobramentos que data do Proterozoico Médio a Superior e é subdividido, dentro do Rio Grande do Sul, em três unidades principais, sendo elas, de oeste para leste: Faixa Tijucas, Batólito Pelotas e Batólito Encruzilhada do Sul (Fragoso-Cesar, 1991). A Faixa Tijucas é constituída por terrenos metamórficos alóctones, ou nappes, e possui formato alongado com eixo maior orientado segundo NE-SW. O Terreno Serra das Encantadas é sua unidade mais proximal com relação ao Grupo Guaritas, apresentando contato tectônico direto com o mesmo, e é formado predominantemente pelos Granitos Miloníticos Porongos, que reúnem granitos miloníticos, quartzo-milonitos e quartzo-mica-xistos, além de escamas tectônicas de gnaisses do embasamento antigo e metassedimentos, como mármores, quartzitos e metapelitos. As demais unidades são compostas essencialmente por xistos micáceos com protólitos vulcânicos e sucessões rítmicas de metapelitos, essencialmente xistos (Fragoso-Cesar, 1991).

O Batólito Pelotas é uma unidade multi-intrusiva que data do Pré-Cambriano Superior, representando uma área mais distal em relação ao Grupo Guaritas (Fragoso-Cesar, 1991). Sua maior unidade, a Suíte Granítica Dom Feliciano, que se estende de Santa Catarina ao Uruguai, é composta

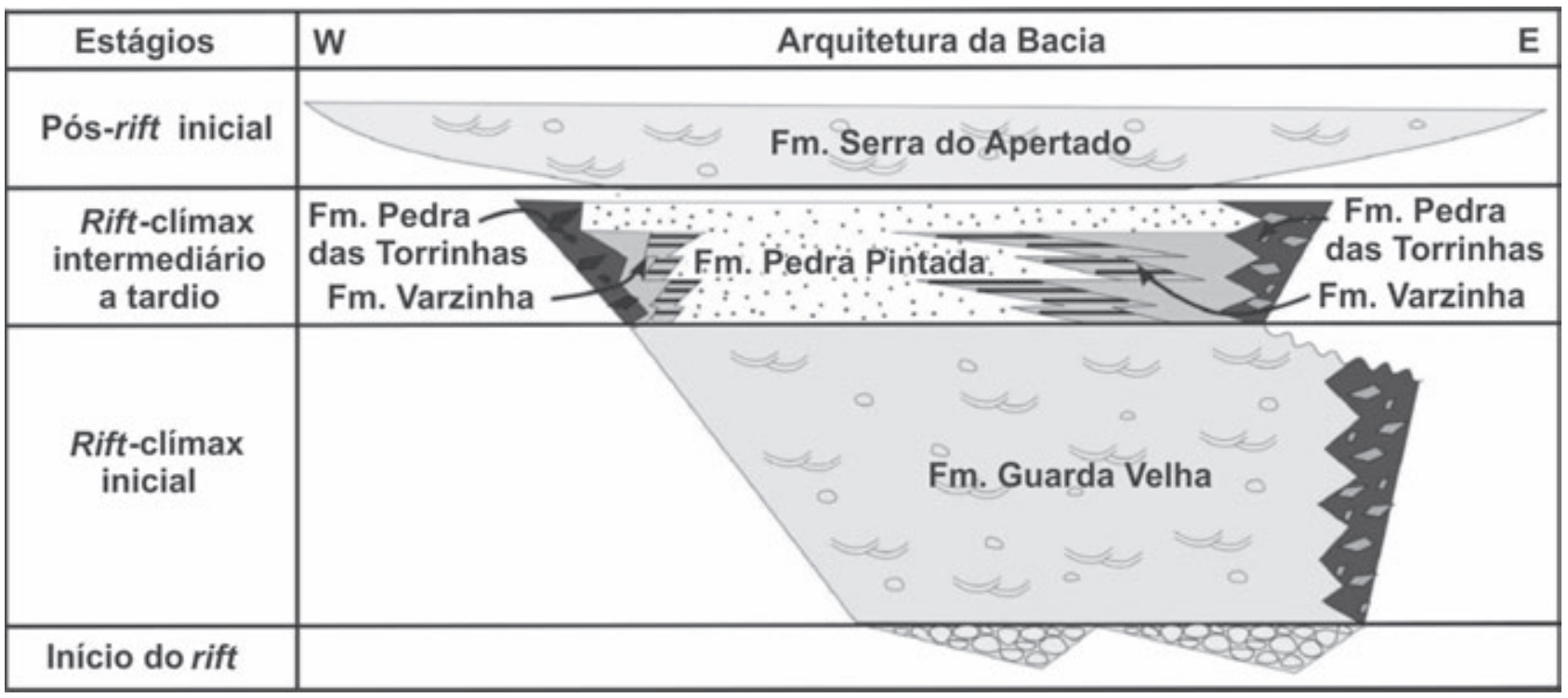

Fm: formação.

Figura 2. Carta estratigráfica do Grupo Guaritas, mostrando as relações laterais e verticais entre suas unidades, segundo Almeida et al. (2009). Extraído de Nóbrega (2011). 
por diversos corpos intrusivos limitados por falhas, tipicamente com sienogranitos e, em menor quantidade, monzogranitos, que variam texturalmente entre granitos porfiríticos róseos-acinzentados e granitos equigranulares grossos avermelhados-róseos. Na borda oeste do Batólito Pelotas, que apresenta contato com a Faixa Tijucas, ocorre uma faixa estreita e alongada de sienogranitos e monzogranitos de cor branca, denominados Leucogranitos Cordilheira. Outras unidades importantes do Batólito Pelotas são o Complexo Granítico-Gnáissico Pinheiro Machado, Gabros Passo da Fabiana, pequenos Plútons Alcalinos e Rochas Hipoabissais e Efusivas, dentre as quais se destacam os Diques Riolíticos Asperezas - enxames de diques com espessura de centímetros a dezenas de metros e extensão de até alguns quilômetros (Fragoso-Cesar, 1991).

O Batólito Encruzilhada do Sul localiza-se a NE do Grupo Guaritas, podendo ser considerado também uma área mais distal com relação ao último; apresenta contato a leste com o Batólito Pelotas, a oeste com a Faixa Tijucas, a norte com a Bacia do Paraná e a noroeste com a Sub-Bacia Camaquã Oriental. O Batólito Encruzilhada do Sul é subdividido nas seguintes unidades: Gnaisses Chanã, Anortosito Capivari, Monzogranito Pitangueiras, Suíte Granítica Encruzilhada do Sul, Sienito Piquiri e stocks graníticos tardios (Fragoso-Cesar, 1991). Sua unidade granítica mais abundante, a Suíte Granítica Encruzilhada do Sul, é composta por sienogranitos e monzogranitos com textura grossa e porfirítica, que localmente passa de forma gradacional para fácies equigranulares rosadas, similares às rochas graníticas da Suíte Dom Feliciano (Fragoso-Cesar, 1991).

\section{O Cinturão Ribeira no Rio Grande do Sul}

O Cinturão Ribeira é um orógeno com idade MesoProterozoica a Eo-Paleozoica, que se estende desde o Estado da Bahia até o Uruguai (Hasui, Carneiro, Coimbra, 1975; Almeida e Hasui, 1984), sendo subdividido em sua porção meridional, no Rio Grande do Sul, nas unidades Terreno Rio Vacacaí, Orógeno Bom Jardim e Plataforma Carbonática Pedreiras (Fragoso-Cesar, 1991). A Plataforma Carbonática Pedreiras aflora em uma pequena área a leste do Alto de Caçapava do Sul, estando diretamente em contato com a borda oeste da Sub-Bacia Camaquã Central. É constituída essencialmente por mármores dolomíticos, com intercalações de quartzitos, meta-margas e rochas básicas (Fragoso-Cesar, 1991).

O Terreno Rio Vacacaí reúne ofiolitos, escamas tectônicas dos Gnaisses Cambaí e rochas supracrustais. As Supracrustais Vacacaí, caracterizadas por rochas metavulcanossedimentares, metagrauvacas, xistos e filitos, e o Granito Caçapava do Sul, unidade heterogênea predominantemente composta por granodioritos e monzogranitos com foliação metamórfica, ocorrem na região do Alto de Caçapava do Sul, portanto, localizadas em uma área proximal em relação ao Grupo Guaritas (Fragoso-Cesar, 1991; Almeida, 2005). Nas áreas a oeste da Sub-Bacia Camaquã Ocidental, ocorrem rochas vulcânicas ácidas a intermediárias da Formação Acampamento Velho e Grupo Bom Jardim, rochas siliciclásticas do Grupo Maricá e granitoides dos stocks Lavras do Sul, Jaguari e Santo Afonso, que podem ser diferenciados do Granito Caçapava do Sul por apresentarem granulação mais grossa, estrutura maciça e, localmente, textura rapakivi (Almeida, 2005).

\section{TRABALHOS ANTERIORES SOBRE A PROVENIÊNCIA SEDIMENTAR DO GRUPO GUARITAS}

Robertson (1966) foi um dos pioneiros na pesquisa da Bacia do Camaquã e definiu a Formação Guaritas, descrevendo-a como rochas de estrutura acamadada predominantemente horizontal, constituídas por brechas de talus, fanglomerados e arcósios de granulação grossa. Desde então, já descreve que as brechas de talus basais da unidade são compostas por seixos e blocos de xistos e granitos, com contribuições locais de clastos provenientes do Membro Andesito Martins. Também descreve que as camadas superiores apresentam seixos com composição representativa de toda a região no entorno e apresentam maior grau de seleção, com seixos mais bem arredondados, o que interpreta como retrabalhamento de sedimentos da Formação Santa Bárbara.

Posteriormente, Ribeiro et al. (1966) descrevem que, na Formação Guaritas, as áreas fonte tiveram controle secundário na composição dos seixos, que é dominada por quartzo, quartzito ou rochas resistentes e que são geralmente bem arredondadas, exceto em regiões muito próximas à área fonte. Segundo os mesmos autores, os sedimentos das porções superiores da Formação Guaritas possuem contribuição de rochas metamórficas.

O primeiro trabalho sistemático que trata da proveniência das fácies fluviais, eólicas e de leques aluviais do Grupo Guaritas é o de De Ros, Morad e Paim (1994). Esses autores classificaram os depósitos do Grupo Guaritas como molássicos, majoritariamente constituídos por arcósios líticos e litoarenitos, com fragmentos líticos de rochas vulcânicas ácidas (principalmente riolitos), rochas metamórficas (metapelitos e mármores) e rochas plutônicas (granitos e gnaisses). Também atestaram que processos diagenéticos, como dissolução de feldspatos, podem influenciar na interpretação de ambientes de proveniência por alterar a composição original dos sedimentos e interpretaram, com base em minerais diagenéticos precoces, clima árido a semiárido durante a deposição do Grupo Guaritas. 
Borba et al. (2003) realizam análises isotópicas pelos métodos $\mathrm{Rb}-\mathrm{Sr}$ e $\mathrm{Sm}-\mathrm{Nd}$ em depósitos pelíticos fluviais, lateralmente correlatos às fácies de arenitos eólicos, na borda leste do Grupo Guaritas. Valores elevados da razão isotópica ${ }^{87} \mathrm{Rb} /{ }^{86} \mathrm{Sr}$ indicam áreas fonte muito ricas em potássio. Comparando seus resultados com demais dados isotópicos das áreas adjacentes, reconhecem similaridade com rochas do Cinturão Dom Feliciano situadas a leste, principalmente os metagranitos Quitéria, Arroio Francisquinho e Cordilheira, e, subordinadamente, rochas vulcânicas da Formação Acampamento Velho e das suítes graníticas Pinheiro Machado e Encruzilhada do Sul. Não reconhecem similaridade com as rochas metamórficas do Complexo Porongos e com o Gnaisse Encantadas, interpretando que tais unidades poderiam estar soterradas ou impedidas de sofrer erosão.

Almeida (2005) descreve em linhas gerais a composição de seixos em sucessões aluviais do Grupo Guaritas e compara algumas diferenças apresentadas entre suas unidades, levando em conta seus elementos arquitetônicos. O autor descreve que ambas as formações Guarda Velha e Serra do Apertado apresentam sentido de paleocorrentes para SW e geralmente seixos arredondados, dominados por rochas vulcânicas ácidas, granitos e quartzo de veio, o que interpreta como indicativo de fontes mais distais situadas ao norte da bacia. Diferentemente, na Formação Pedra das Torrinhas e porções proximais da Formação Varzinha, predominam clastos angulosos de quartzo milonitos e filonitos, cuja área fonte reside a leste, na Serra das Encantadas. Na Formação Pedra das Torrinhas, a proveniência dos seixos também pode ser controlada pelos tipos de ambientes deposicionais, como os elementos arquitetônicos LD - lobos de fluxo de detritos -, com predomínio de filitos, e CE - canais de rios efêmeros -, com granitos e vulcânicas ácidas (Almeida, 2005).

Em seguida, Hartmann, Santos e McNaughton (2008) aplicam o método de datação U-Pb em cristais de zircão de um arenito pertencente ao Grupo Guaritas, encontrando duas populações principais de zircões, a mais abundante com idade entre 2.260 e $2.004 \mathrm{Ma}$, que relacionam ao ciclo Transamazônico, e outra com idade entre 844 e 535 Ma, que relacionam ao ciclo Brasiliano, além de uma quantidade menor de cristais com idades Arqueana (2.525 $2.766 \mathrm{Ma})$, Paleoproterozoica (1.995 - $1.634 \mathrm{Ma})$ e Mesoproterozoica (1.352 - 1.369 Ma). Com base nesse estudo, interpretam que a principal fonte para os sedimentos do Grupo Guaritas foram rochas do ciclo Transamazônico, com idades entre 2.260 e $2.004 \mathrm{Ma}$.

Nóbrega, Sawakuchi e Almeida (2008) fazem um estudo de proveniência através de minerais pesados, definindo alguns critérios comparativos entre as unidades do Grupo Guaritas. A Formação Serra do Apertado se diferencia das formações Pedra Pintada e Varzinha por possuir maior grau de retrabalhamento sedimentar, acusado por valores de índice ZTR mais elevados, e maior contribuição direta de fontes ígneas, devido à maior abundância de cristais euédricos de zircão. Segundo os autores, rochas graníticas teriam sido a principal área fonte para o Grupo Guaritas, devido ao predomínio da associação mineralógica zircão-apatita-turmalina-granada encontrada.

Posteriormente, Marconato et al. (2009) apresentam estudos de proveniência em depósitos de leques aluviais, referentes à Formação Pedra das Torrinhas, e fluviais entrelaçados, pertencentes à Formação Serra do Apertado, próximos da borda leste do Grupo Guaritas. Identificam que, apesar das paleocorrentes similares em ambos os ambientes de sedimentação, com sentido do vetor resultante para NW, na Formação Pedra das Torrinhas predominam seixos compostos por quartzo milonito e granito milonítico, com menor contribuição de clorita xistos, enquanto na Formação Serra do Apertado, a proveniência é mais diversificada, com seixos e calhaus de granitos, granitos miloníticos, riolitos e quartzo milonitos. A partir desses dados, interpretam que a área fonte dos leques aluviais situavase próximo à borda da bacia, onde afloram os Granitos Miloníticos Porongos (sensu Fragoso-Cesar, 1991), enquanto os rios entrelaçados apresentavam maior área de captação, devido à diversidade de litotipos encontrada.

Almeida et al. (2009) realizam contagens de seixos em cada uma das unidades do Grupo Guaritas, utilizando tais dados como um dos suportes na interpretação da evolução da bacia do "rift Guaritas" e de sua paleogeografia. Segundo seus estudos, as fases de iniciação e clímax primário do rift, representadas pela Formação Guarda Velha, são marcadas por um sistema fluvial axial, com transporte para SW, e seixos compostos predominantemente por granitos e rochas vulcânicas arredondadas, indicando proveniência de fontes distais situadas a norte. As fases de clímax médio a tardio do rift, representadas pelas formações Varzinha, Pedra das Torrinhas e Pedra Pintada, apresentam sistemas de leques aluviais e de rios efêmeros com transporte para $\mathrm{W}$, com abundância de seixos de granitos miloníticos e quartzo milonitos, indicando fontes situadas a leste. Em algumas porções da Formação Varzinha e nas fácies de interdunas do sistema eólico da Formação Pedra Pintada, ocorrem seixos de granitos e rochas vulcânicas, similares à proveniência do sistema fluvial axial. Por fim, no estágio pós-rift, representado pela Formação Serra do Apertado, tornariam a ocorrer seixos arredondados dominados por rochas graníticas e vulcânicas, com transporte para SW, indicando novamente o domínio de um sistema fluvial axial.

\section{ANÁLISE DE PROVENIÊNCIA}

Foram coletados dados de proveniência em 33 sítios de amostragem distintos, nas formações Guarda Velha, 
Varzinha, Pedra Pintada, Pedra das Torrinhas e Serra do Apertado (sensu Almeida, 2005; Almeida et al., 2009). A distribuição espacial dos sítios de amostragem na área de estudo, assim como as unidades estratigráficas às quais pertencem, estão representadas no mapa da Figura 3.
Os seixos, calhaus e matacões descritos em arenitos conglomeráticos e conglomerados foram agrupados em 13 classes de litotipos distintas, sendo elas: andesito, aplito, arenito, metassedimentos — que inclui filitos, xistos, filonitos, metaconglomerados e metarenitos, granitos - que

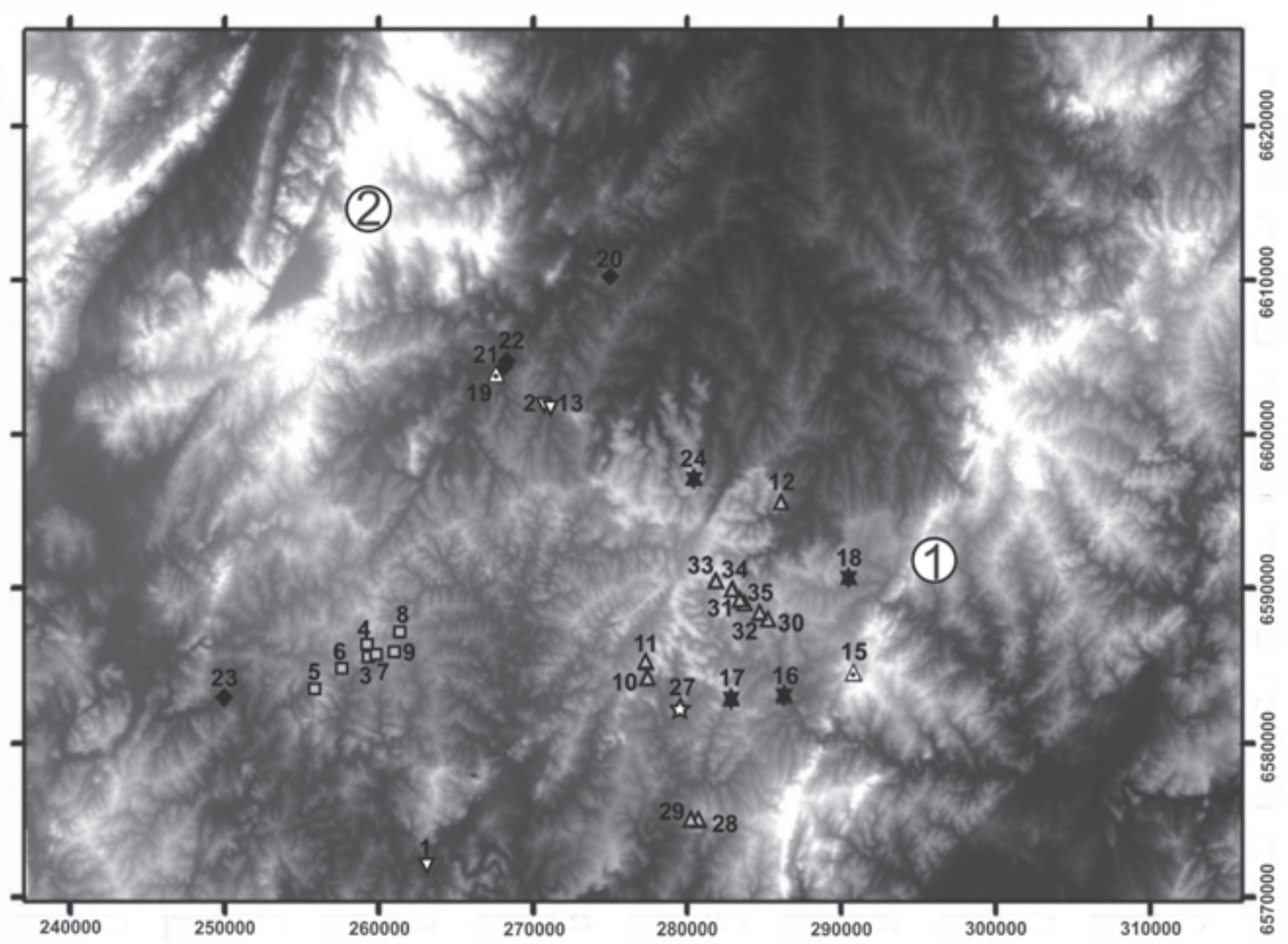

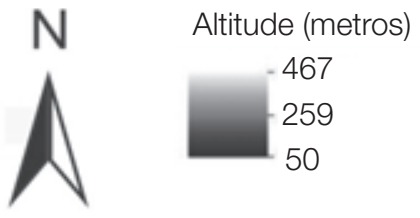

จ Formação Guarda Velha sistema fluvial e iniciação do rift

c Formação Guarda Velha sistema fluvial transversal
Escala gráfica

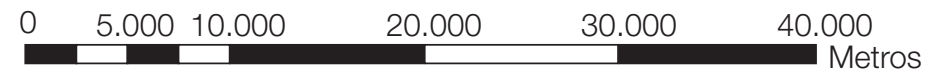

Legenda

Formação Guarda Velha - $\quad \Delta$ Formação Pedra das Torrinhas sistema de rio tronco

* Formação Varzinha

$\Delta$ Formação Serra do Apertado

Formação Pedra Pintada

Figura 3. Localização dos pontos de amostragem para análise de proveniência macroscópica. 1: Serra das Encantadas; 2: Alto de Caçapava do Sul. Na região central do mapa, localizam-se os pontos dentro do Grupo Guaritas, na Sub-Bacia Camaquã Central. A legenda mostra as unidades estratigráficas às quais os pontos de amostragem pertencem. Imagem SRTM extraída de: http://www.relevobr.cnpm.embrapa.br/download/index.htm. 
inclui granitos, sienogranitos, monzogranitos e monzodioritos, podendo apresentar biotita ou anfibólio, granitos miloníticos - granitos, monzogranitos, sienogranitos e quartzo monzonitos milonitizados, leucogranito, pegmatito, quartzito - que inclui quartzitos maciços e orientados, quartzo de veio, quartzo milonito, riolito que inclui riolitos e vulcânicas ácidas, e sienito.

Os dados composicionais obtidos a partir da contagem de seixos, calhaus e matacões estão sumarizados em gráficos de porcentagem das classes de seixos observadas (Tabela 1 e Figura 4). A técnica multivariada usada no presente estudo é a análise por principais componentes, escolhida por mostrar a importância relativa de cada variável de um sistema, segundo a Equação 1 (Davis, 1986). Essa técnica consiste em reduzir o número de variáveis, a fim de facilitar a comparação entre os conjuntos de dados, sem que ocorra uma perda de parte significativa da variância total.

$\mathrm{Y}_{1}=\alpha_{1} \mathrm{X}_{1}+\alpha_{2} \mathrm{X}_{2}+\ldots+\alpha_{\mathrm{n}} \mathrm{X}_{\mathrm{n}}$

$\mathrm{Y}_{2}=\beta_{1} \mathrm{X}_{1}+\beta_{2} \mathrm{X}_{2}+\ldots+\beta_{\mathrm{n}} \mathrm{X}_{\mathrm{n}}$

Onde $\mathrm{Y}$ corresponde às principais componentes, sendo que $\mathrm{Y}_{1}$ contém uma maior porcentagem de variância que $\mathrm{Y}_{2} \mathrm{e}$ assim sucessivamente até $Y_{n} ; \alpha$ e $\beta$ correspondem a fatores de pesos proporcionais aos autovalores (eigenvalues) da matriz de variância-covariância, que, somados, resultam na variância total; e X corresponde às variáveis originais.

\section{Formação Guarda Velha}

Os depósitos da Formação Guarda Velha são interpretados como de ambiente fluvial dominado por carga de fundo (Almeida, 2005; Paim e Scherer, 2007) e nela foram realizadas contagens de seixos em 14 sítios de amostragem distintos com ampla distribuição lateral (Figura 3). Os seixos desta unidade são dominados pelas classes granito e riolito, que variam de aproximadamente 10 a $50 \%$ e 9 a $62 \%$ da composição total, respectivamente. Também ocorrem de forma expressiva as classes quartzo de veio, quartzo milonito, metassedimentos e granitos miloníticos e, em menor proporção, arenito, sienito, aplito, andesito, leucogranito e quartzito (Figura 4).

De acordo com os trabalhos de Paim (1995), Almeida (2005) e Santos (2010), a Formação Guarda Velha apresenta diferentes ambientes deposicionais que coexistiram lateralmente. Na região oeste e noroeste da unidade, o ambiente deposicional é caracterizado por um sistema de rio tronco que corria paralelo à direção do eixo maior da bacia, como indicado pelas paleocorrentes com sentido de transporte para SW (Paim, 1995; Almeida, 2005). Nos depósitos situados a leste, na região da Serra das Guaritas, o ambiente deposicional é marcado por um sistema de rios transversais distributários, marcados por altas variações de vazão e paleocorrentes com sentido de transporte para NW (Paim, 1995; Santos, 2010). Os depósitos da base da Formação Guarda Velha são caracterizados por espessas camadas de conglomerados, intercalados com arenitos conglomeráticos, que são interpretados por Almeida (2005) e Santos (2010) como depósitos da fase de iniciação do rift.

A análise por principais componentes foi realizada para comparar a composição de seixos entre os diferentes sítios de amostragem e avaliar se ocorrem agrupamentos composicionais internos a essa unidade. A principal componente 1 (PC1) e a principal componente 2 (PC2), que correspondem respectivamente a 32 e $18 \%$ da variância total do conjunto de dados, podem ser descritas pelas Equações 2 e 3:

PC1 = 0,305and $-0,235 a p l-0,309 a r n-0,433 m t s+$ 0,372 grn mil $+0,045 \mathrm{grn}+0,018$ leuc $+0,209 \mathrm{peg}+0,213 q \mathrm{qtz}$ $-0,309 q t z$ veio $+0,309 q t z$ mil $-0,187$ rio $+0,338$ sie

PC2 $=-0,041$ and $-0,036 a p l+0,280 a r n+0,193 m t s-$ $0,196 \mathrm{grn}$ mil $-0,259 \mathrm{grn}-0,483$ leuc $-0,034 \mathrm{peg}+0,371$ qtzt $-0,3746 q$ tz veio $-0,268$ qtz mil $-0,313$ rio $+0,306$ sie

Onde: and: andesito; apl: aplito; arn: arenito; mts: metassedimentos; grn mil: granito milonítico; grn: granito; leuc: leucogranito; peg: pegmatito; qtzt: quartzito; qtz veio: quartzo de veio; qtz mil: quartzo milonito; rio: riolito; sie: sienito.

O gráfico da Figura 5 mostra o resultado obtido por meio dessa análise multivariada.

Com base na Figura 5, é possível observar que dois agrupamentos principais foram gerados pela composição de seixos: um que apresenta valores exclusivamente positivos da primeira componente, variando entre valores positivos e negativos da segunda componente, e outro com valores exclusivamente negativos da primeira componente, que varia entre valores negativos e positivos da segunda. $\mathrm{O}$ gráfico da Figura 5 também mostra que há uma forte correlação entre os agrupamentos e os ambientes deposicionais de sistema de rio tronco, sistema de rios transversais e fase de iniciação de rift descritos na literatura.

A oeste e noroeste os depósitos apresentam proporções mais baixas de granitos miloníticos e quartzo milonitos, variando de 0,5 a $12 \%$ e 0,0 a $22 \%$, respectivamente, enquanto na região da Serra das Guaritas as proporções dessas classes de seixos são mais elevadas, variando de 7 a $23 \%$ e 12 a $40 \%$, respectivamente, como pode ser observado no gráfico de pesos (loading plot) da Figura 5B e na Figura 4. Os depósitos das regiões oeste e noroeste também são mais polimíticos em relação aos depósitos situados a leste, ocorrendo comumente classes 
Tabela 1. Porcentagem das classes de seixos presentes em cada ponto de amostragem.

\begin{tabular}{|c|c|c|c|c|c|c|c|c|c|c|c|c|c|c|c|c|c|}
\hline $\begin{array}{l}\text { O̊ } \\
\stackrel{0}{ \pm} \\
0 \\
0\end{array}$ & $\begin{array}{l}\frac{0}{0} \\
\frac{\pi}{0} \\
\frac{0}{c}\end{array}$ & $\begin{array}{l}\frac{0}{5} \\
\frac{1}{0} \\
\frac{0}{2}\end{array}$ & $\frac{0}{\frac{1}{2}}$ & 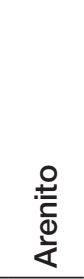 & 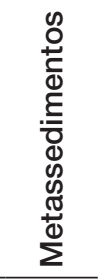 & 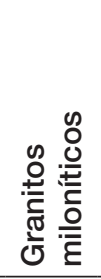 & 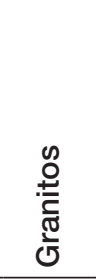 & 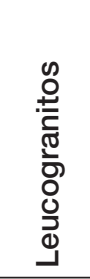 & 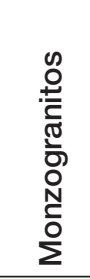 & 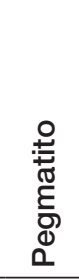 & $\begin{array}{l}0 \\
\frac{0}{1} \\
\frac{1}{1} \\
\frac{\pi}{2} \\
0 \\
0\end{array}$ & $\begin{array}{l}\frac{0}{0} \\
> \\
0 \\
0 \\
\circ \\
\frac{N}{0} \\
\frac{N}{2} \\
0\end{array}$ & 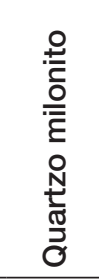 & 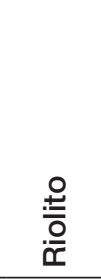 & 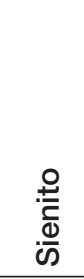 & 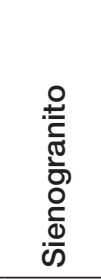 & $\begin{array}{l}\text { तु } \\
\text { 믐 }\end{array}$ \\
\hline 1 & Guarda Velha & 4,98 & 0,00 & 0,00 & 0,00 & 2,33 & 0,00 & 14,17 & 23,84 & 0,00 & 0,00 & 9,67 & 10,40 & 34,25 & 0,00 & 0,26 & 99,89 \\
\hline 2 & Guarda Velha & 0,00 & 0,00 & 0,00 & 2,26 & 7,62 & 0,00 & 2,64 & 3,92 & 0,00 & 1,28 & 15,09 & 22,32 & 38,34 & 0,00 & 6,53 & 100,00 \\
\hline 3 & Guarda Velha & 1,99 & 0,00 & 0,00 & 0,00 & 22,71 & 0,00 & 0,24 & 2,92 & 0,00 & 0,00 & 14,69 & 13,64 & 31,57 & 0,00 & 12,24 & 100,00 \\
\hline 4 & Guarda Velha & 0,00 & 0,00 & 0,00 & 0,00 & 11,95 & 1,41 & 1,64 & 10,66 & 0,00 & 0,00 & 10,29 & 11,84 & 42,17 & 0,00 & 10,03 & 100,00 \\
\hline 5 & Guarda Velha & 1,03 & 0,00 & 0,00 & 0,00 & 10,37 & 0,08 & 0,00 & 2,51 & 0,00 & 2,26 & 4,01 & 18,35 & 38,95 & 0,00 & 22,42 & 100,00 \\
\hline 6 & Guarda Velha & 3,61 & 0,00 & 0,00 & 0,00 & 13,27 & 0,00 & 0,00 & 3,99 & 0,00 & 3,73 & 1,66 & 24,62 & 20,08 & 1,45 & 27,57 & 100,00 \\
\hline 7 & Guarda Velha & 0,09 & 0,00 & 0,00 & 0,00 & 10,24 & 0,00 & 0,00 & 2,60 & 0,00 & 4,23 & 9,20 & 39,59 & 13,27 & 0,00 & 20,77 & 100,00 \\
\hline 9 & Guarda Velha & 0,12 & 0,00 & 0,00 & 0,00 & 7,45 & 0,00 & 0,00 & 0,95 & 0,00 & 0,76 & 21,36 & 13,72 & 26,59 & 0,00 & 28,91 & 99,86 \\
\hline 10 & $\begin{array}{l}\text { Serra do } \\
\text { Apertado }\end{array}$ & 0,00 & 0,93 & 0,00 & 2,73 & 3,74 & 28,53 & 0,00 & 0,00 & 0,03 & 1,27 & 6,80 & 3,67 & 52,30 & 0,00 & 0,00 & 100,00 \\
\hline 12 & $\begin{array}{l}\text { Serra do } \\
\text { Apertado }\end{array}$ & 0,45 & 0,38 & 0,00 & 0,80 & 7,51 & 30,30 & 0,66 & 0,00 & 0,68 & 4,59 & 11,65 & 6,29 & 26,34 & 0,00 & 10,32 & 100,00 \\
\hline 13 & Guarda Velha & 0,00 & 0,00 & 0,00 & 1,35 & 1,37 & 9,05 & 0,00 & 0,00 & 0,00 & 4,55 & 15,61 & 1,62 & 59,60 & 0,00 & 6,86 & 100,00 \\
\hline 15 & $\begin{array}{l}\text { Pedra das } \\
\text { Torrinhas }\end{array}$ & 0,00 & 0,00 & 0,00 & 2,28 & 5,80 & 0,00 & 0,00 & 0,00 & 0,00 & 0,00 & 0,00 & 91,93 & 0,00 & 0,00 & 0,00 & 100,00 \\
\hline 16 & Varzinha & 1,04 & 0,00 & 2,83 & 22,78 & 22,18 & 0,00 & 0,00 & 0,00 & 0,00 & 0,00 & 0,00 & 48,54 & 2,63 & 0,00 & 0,00 & 100,00 \\
\hline 17 & Varzinha & 1,27 & 4,62 & 0,17 & 5,07 & 7,46 & 5,49 & 5,17 & 3,84 & 0,00 & 0,00 & 5,50 & 26,51 & 27,38 & 0,50 & 7,04 & 100,00 \\
\hline 18 & Varzinha & 0,00 & 5,72 & 0,00 & 4,00 & 11,14 & 18,46 & 2,12 & 0,13 & 0,00 & 0,00 & 6,47 & 28,46 & 20,07 & 0,22 & 3,23 & 100,00 \\
\hline 19 & Guarda Velha & 1,04 & 0,00 & 1,57 & 6,66 & 0,99 & 0,66 & 0,00 & 0,00 & 0,00 & 0,16 & 21,89 & 0,00 & 27,37 & 0,00 & 39,65 & 100,00 \\
\hline 19 & $\begin{array}{c}\text { Pedra das } \\
\text { Torrinhas }\end{array}$ & 0,00 & 0,00 & 0,31 & 80,41 & 1,23 & 5,50 & 0,00 & 1,84 & 0,00 & 0,00 & 0,00 & 2,17 & 5,98 & 0,00 & 2,55 & 100,00 \\
\hline 20 & Guarda Velha & 0,00 & 2,55 & 4,71 & 5,42 & 2,14 & 0,00 & 0,00 & 0,00 & 0,00 & 0,00 & 10,13 & 0,57 & 61,79 & 0,00 & 12,69 & 100,00 \\
\hline 21 & Guarda Velha & 0,00 & 0,00 & 1,36 & 8,56 & 5,22 & 0,00 & 0,00 & 0,00 & 0,00 & 0,00 & 6,86 & 4,79 & 30,23 & 0,00 & 42,99 & 100,00 \\
\hline 22 & Guarda Velha & 0,00 & 0,20 & 0,00 & 5,77 & 0,44 & 0,00 & 1,12 & 0,00 & 0,00 & 0,00 & 33,92 & 5,93 & 27,92 & 0,00 & 24,71 & 100,00 \\
\hline 23 & Guarda Velha & 0,00 & 2,68 & 0,00 & 0,28 & 12,43 & 0,00 & 0,00 & 0,00 & 0,00 & 0,00 & 16,31 & 8,69 & 9,19 & 0,00 & 50,41 & 100,00 \\
\hline 24 & Varzinha & 0,00 & 2,82 & 0,00 & 3,13 & 0,99 & 0,00 & 0,00 & 0,00 & 0,00 & 0,00 & 72,42 & 8,55 & 0,52 & 0,00 & 11,58 & 100,00 \\
\hline 27 & Pedra Pintada & 0,00 & 0,00 & 0,00 & 39,20 & 2,67 & 0,00 & 0,00 & 0,00 & 0,00 & 0,00 & 4,86 & 48,90 & 2,64 & 0,00 & 1,72 & 100,00 \\
\hline 28 & $\begin{array}{l}\text { Serra do } \\
\text { Apertado }\end{array}$ & 0,00 & 0,00 & 0,00 & 1,72 & 2,57 & 34,37 & 1,94 & 0,05 & 0,00 & 0,00 & 8,89 & 6,25 & 44,21 & 0,00 & 0,00 & 100,00 \\
\hline 29 & Pedra Pintada & 0,00 & 0,00 & 0,00 & 2,20 & 13,59 & 1,14 & 0,00 & 0,17 & 0,00 & 0,00 & 10,97 & 71,93 & 0,00 & 0,00 & 0,00 & 100,00 \\
\hline 29 & $\begin{array}{l}\text { Serra do } \\
\text { Apertado }\end{array}$ & 0,00 & 0,00 & 0,00 & 1,52 & 6,05 & 19,40 & 0,00 & 0,00 & 0,00 & 0,00 & 8,06 & 20,73 & 44,23 & 0,00 & 0,00 & 100,00 \\
\hline 30 & Pedra Pintada & 0,00 & 0,00 & 0,00 & 2,58 & 4,23 & 6,68 & 0,00 & 0,00 & 0,00 & 0,00 & 7,64 & 67,13 & 11,73 & 0,00 & 0,00 & 100,00 \\
\hline 30 & $\begin{array}{l}\text { Serra do } \\
\text { Apertado }\end{array}$ & 0,00 & 0,41 & 0,00 & 0,19 & 2,73 & 27,37 & 0,00 & 0,00 & 0,00 & 0,00 & 25,54 & 9,56 & 34,20 & 0,00 & 0,00 & 100,00 \\
\hline 31 & $\begin{array}{l}\text { Serra do } \\
\text { Apertado }\end{array}$ & 0,00 & 0,00 & 0,00 & 0,85 & 0,38 & 57,54 & 4,98 & 0,00 & 0,00 & 0,00 & 5,61 & 8,83 & 21,82 & 0,00 & 0,00 & 100,00 \\
\hline 32 & $\begin{array}{l}\text { Serra do } \\
\text { Apertado }\end{array}$ & 0,00 & 0,00 & 0,00 & 3,04 & 3,19 & 29,25 & 0,15 & 0,00 & 0,00 & 0,00 & 21,54 & 14,32 & 28,50 & 0,00 & 0,00 & 100,00 \\
\hline 33 & $\begin{array}{l}\text { Serra do } \\
\text { Apertado }\end{array}$ & 0,00 & 0,00 & 0,00 & 4,37 & 6,40 & 23,61 & 0,00 & 0,00 & 0,00 & 0,00 & 35,12 & 24,48 & 6,01 & 0,00 & 0,00 & 100,00 \\
\hline 34 & $\begin{array}{l}\text { Serra do } \\
\text { Apertado }\end{array}$ & 0,00 & 0,16 & 0,00 & 0,72 & 2,93 & 42,01 & 0,00 & 0,00 & 0,00 & 0,00 & 25,80 & 14,08 & 14,31 & 0,00 & 0,00 & 100,00 \\
\hline 35 & $\begin{array}{l}\text { Serra do } \\
\text { Apertado }\end{array}$ & 0,00 & 47,43 & 0,00 & 1,42 & 2,33 & 0,00 & 0,00 & 0,00 & 0,00 & 0,00 & 13,31 & 21,37 & 14,14 & 0,00 & 0,00 & 100,00 \\
\hline
\end{tabular}


Formação Pontos

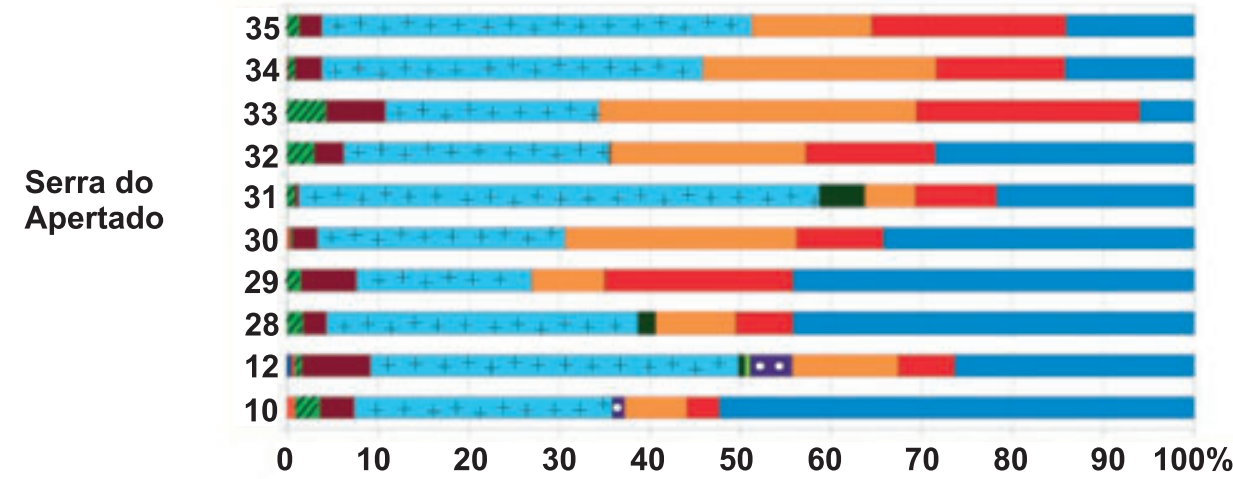

Pedra das

Torrinhas

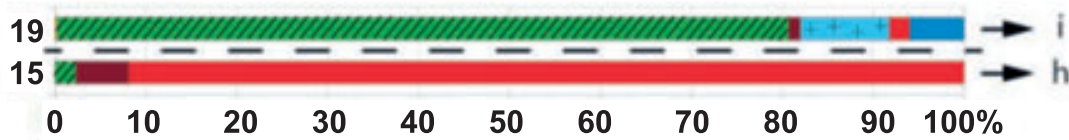

Pedra

Pintada

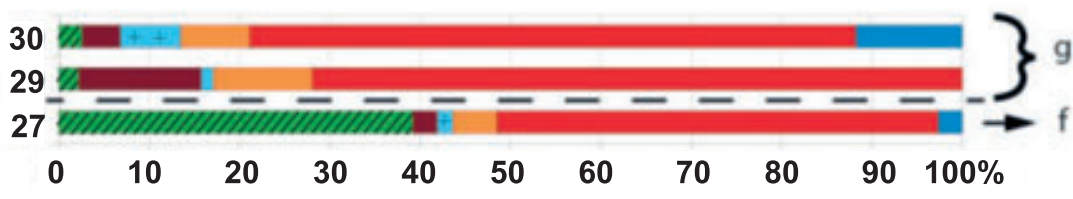

Varzinha
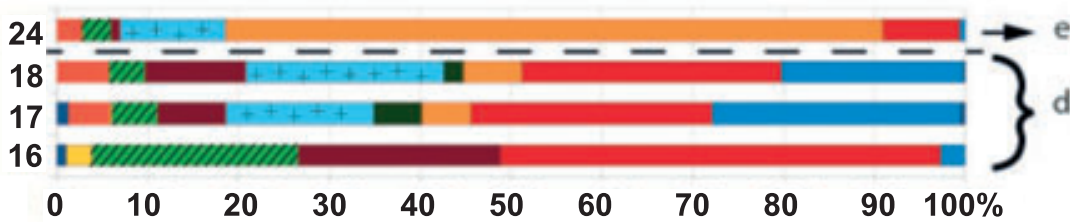

Legendas

- Sienito

Riolito

auartzo milonito

Quartzo de

veio

- Quartzitos

Eegmatitos

- Leucogranitos

* Granitos

- Granitos miloníticos

थ Metassedimentos

arenito

Aplito

Andesito

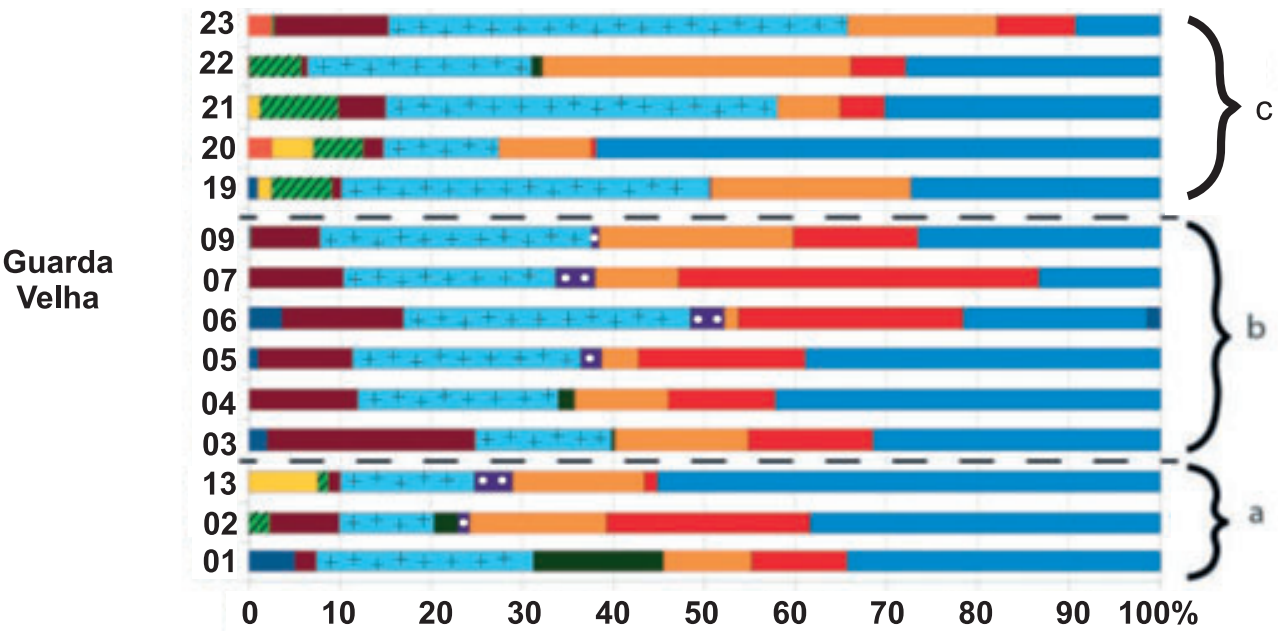

A ordem dos pontos encontra-se aproximadamente de acordo com a estratigrafia do Grupo Guaritas, sendo que os depósitos mais antigos encontram-se na base e os mais recentes, no topo; a: depósitos da fase de iniciação do rift; b: depósitos do sistema de rios transversais distributários; c: depósitos do sistema de rio tronco; d: depósitos da borda leste da unidade; e: depósitos da região central da unidade; f: depósitos da porção estratigraficamente intermediária da unidade; g: depósitos do topo da unidade; h: depósitos da borda leste da unidade; i: depósitos da borda oeste da unidade.

Figura 4. Porcentagem das classes de seixos destacando as proporções relativas entre cada ponto de amostragem. 


\section{Formação Guarda Velha}

A

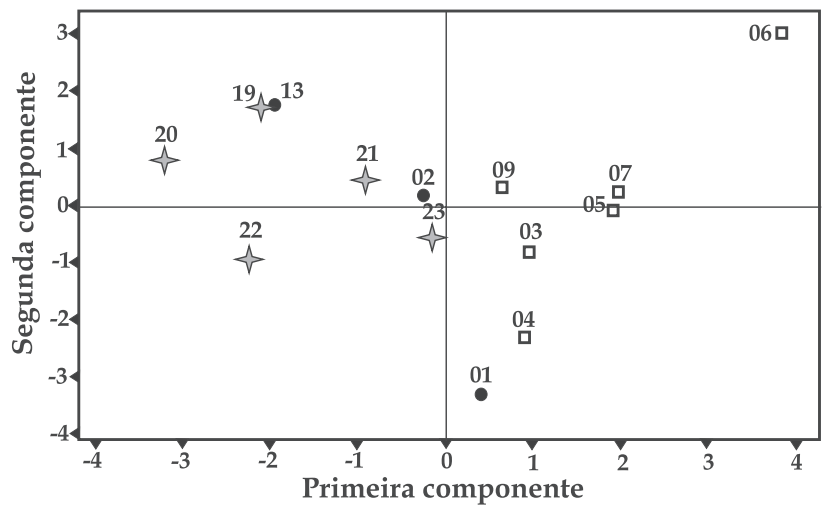

B

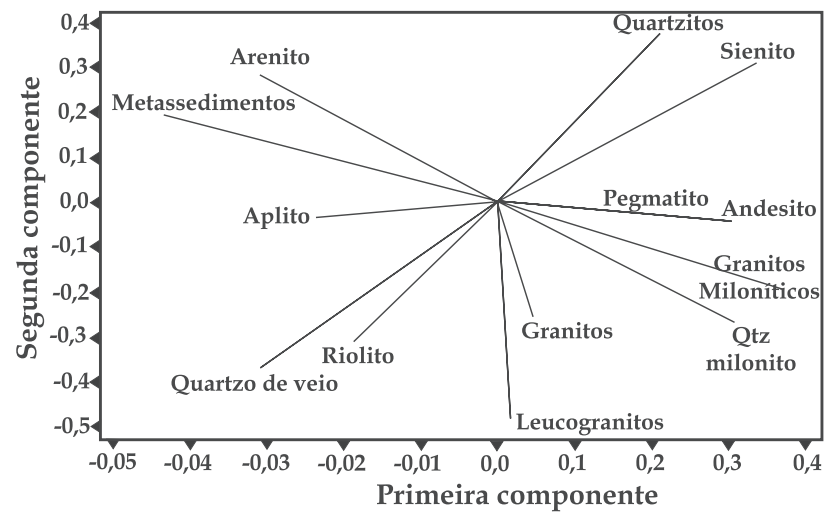

Legendas
- Depósitos da fase de iniciação do rift

$\square$ Depósitos do sistema de rios transversais $\checkmark$ Depósitos do sistema de rio tronco

04 Pontos de amostragem

No gráfico, é possível observar dois agrupamentos principais, um com valores positivos da primeira componente e outro com valores negativos da mesma, que se correlacionam com os diferentes tipos de ambientes deposicionais. Qtz: quartzo.

Figura 5. Gráficos de espalhamento (scater plot) (A) e de pesos (loading plot) (B) da análise por principais componentes a partir dos dados composicionais de seixos da Formação Guarda Velha.

de seixos como metassedimentos, arenitos e, em menor proporção, aplitos. Já os depósitos situados na base da Formação Guarda Velha apresentam baixas proporções de classes de rochas miloníticas, variando de 7 a $10 \%$ e 2 a $7 \%$ para quartzo milonito e granitos miloníticos, respectivamente. Esses depósitos são tão polimíticos como os depósitos do sistema de rio tronco, apresentando classes de seixos como aplito, andesito, arenito e leucogranito, mas se diferenciam desse último sistema por apresentarem proporções mais elevadas de aplito e leucogranito, como pode ser observado no gráfico de pesos (loading plot) da Figura 5B e na Figura 4.

Dessa forma, as altas proporções de granitos miloníticos e quartzo milonitos observadas nos depósitos da Serra das Guaritas são interpretadas como contribuições de fontes situadas a leste, como os Granitos Miloníticos Porongos (sensu Fragoso-Cesar, 1991), correspondendo positivamente às interpretações de Santos (2010) sobre a presença de um sistema fluvial distributário transversal. A maior diversidade de litotipos nos depósitos das regiões oeste e noroeste indicam um sistema fluvial com maior área de captação e corrobora a interpretação de estudos anteriores da presença de um rio tronco nessa região (Paim, 1995; Almeida, 2005), com áreas fonte situadas a norte.

Nos depósitos da fase de iniciação do rift, foi observado que a proveniência apresenta uma certa dicotomia, pois, como demonstrado no gráfico da Figura 5, os pontos 02 e 13, localizados no Passo da Guarda Velha, se assemelham mais aos depósitos de sistema de rio tronco, enquanto que o ponto 01, localizado no Passo do Cação, se assemelha aos depósitos do sistema de rios transversais distributários. Os estudos de Santos (2010) mostram que na região do Passo do Cação o elemento arquitetônico dominante é caracterizado por barras conglomeráticas espessas, com algumas intercalações com sets de arenitos conglomeráticos com estratificação cruzada acanalada. Já na região do Passo da Guarda Velha, a sucessão sedimentar se inicia com depósitos conglomeráticos espessos, mas seção acima grada para elementos mais ricos em fácies arenosas, caracterizando uma fase de transição para elementos arquitetônicos dominados por uma granulometria mais fina. Além de ter sido observada uma diferença de composição nos depósitos da fase de iniciação do rift Guaritas, os estudos de Santos (2010) mostram que ocorre uma diferenciação por tipos de fácies e granulometria dominantes.

Dessa forma, consideramos a hipótese de que a fase de iniciação do rift Guaritas apresenta áreas fonte situadas a leste para depósitos dominados por fácies conglomeráticas, com presença de matacões, característicos de fontes mais proximais e com composição de seixos que se assemelha aos depósitos dos sistemas de rios transversais distributários, e fontes situadas a norte para os depósitos com maior ocorrência de fácies areno-conglomeráticas, características de uma maior maturidade do sedimento transportado e com composição que se assemelha mais ao sistema de rio tronco. 


\section{Formação Varzinha}

Os depósitos da Formação Varzinha são interpretados como de ambiente fluvial, dominados por carga mista (Almeida, 2005; Paim e Scherer, 2007). Nessa formação, foram realizadas contagens de seixos em quatro sítios de amostragem, sendo três localizados na borda leste da unidade, próximos ao alto da Serra das Encantadas, e um na porção central da unidade. Nos depósitos da borda leste, correspondentes aos pontos de amostragem 17, 16 e 18 (Figura 3), a classe de seixos dominante é o quartzo milonito, que varia entre 26 e $48 \%$ da composição total; ocorrem também, em significativas proporções, seixos das classes granitos miloníticos, granitos, riolitos e metassedimentos e, em menor proporção, as classes aplitos, andesitos, arenitos, leucogranitos e sienitos (Figura 4). Os depósitos da porção central, representados pelo ponto de amostragem 24 (Figura 3), são dominados por seixos de quartzo de veio, representando $72 \%$ da composição total, ocorrendo também quartzo milonitos, granitos, granitos miloníticos, aplitos, metassedimentos e sienitos (Figura 4).

A elevada proporção de quartzo de veio observada nos depósitos da porção central da Formação Varzinha indica possivelmente fontes mais distais e maior retrabalhamento. Como o quartzo de veio representa uma porcentagem muito pequena da rocha fonte, deve haver grandes distâncias de transporte para que se acumule em grandes quantidades no depósito e, possivelmente, policiclicidade. Os depósitos situados a leste apresentam proporções mais elevadas de rochas miloníticas e metassedimentos, sugerindo que suas áreas fontes situam-se a leste, na Serra das Encantadas.

Segundo Almeida (2005), a Formação Varzinha apresenta paleocorrentes com sentido de transporte para sudoeste na região central da unidade, enquanto na borda leste da mesma o sentido de transporte é para noroeste. Dessa forma, as diferenças observadas entre as composições de seixos para as regiões central e leste da Formação Varzinha corroboram os dados de paleocorrentes de Almeida (2005), indicando diferentes áreas fonte para a unidade. Os clastos depositados na região central sofreram provavelmente maior transporte e foram trazidos para a bacia por um rio com área de captação mais distal, provavelmente situada a norte, enquanto os sedimentos depositados na região leste sofreram transporte mais curto e preservam bem a assembleia de litotipos de sua área fonte a leste, na Serra das Encantadas.

\section{Formação Pedra Pintada}

Os depósitos da Formação Pedra Pintada são interpretados como de ambiente de campos de dunas eólicas (FragosoCesar, 1991; Paim, 1994; Almeida, 2005) com interdunas fluviais (Almeida, 2005; Paim e Scherer, 2007) e nela foram realizadas contagens de seixos apenas nas fácies subaquáticas em três sítios de amostragem, dois pertencentes ao topo da unidade, em contato com a Formação Serra do Apertado sobreposta, que correspondem aos pontos 29 e 30 , e um situado em uma porção estratigraficamente intermediária da unidade, correspondente ao ponto 27. Os depósitos de topo apresentam franco predomínio de seixos de quartzo milonito, que variam de 49 a $72 \%$ da composição total, ocorrendo em menores proporções clastos de granitos, granitos miloníticos, quartzo de veio, riolitos e metassedimentos (Figura 4). Os depósitos da porção intermediária da unidade apresentam significativa contribuição de metassedimentos e quartzo milonitos que representam, respectivamente, 39 e $49 \%$ da composição total, ocorrendo também riolitos, granitos, granitos miloníticos e quartzo de veio (Figura 4).

Segundo Almeida (2005), os depósitos de interdunas fluviais da Formação Pedra Pintada apresentam paleocorrentes com sentido de transporte principal para noroeste. A grande quantidade de quartzo milonito encontrada nos depósitos dessa unidade, assim como a presença em menor quantidade de rochas metamórficas de baixo grau, granitos e riolitos, indicam área fonte situada a leste, na Serra das Encantadas. Como as rochas pertencentes à classe metassedimentos são pouco resistentes ao transporte, sua maior presença em depósitos da porção intermediária da Formação Pedra Pintada pode indicar fontes mais proximais, ou climas mais áridos, enquanto que a diminuição em porcentagem da classe metassedimentos e aumento na de quartzo milonito, quartzo de veio, granitos e riolitos para o topo da unidade pode representar fontes mais distais, ou climas mais úmidos.

\section{Formação Pedra das Torrinhas}

Os depósitos da Formação Pedra das Torrinhas são interpretados como de ambiente de leques aluviais e ocorrem predominantemente na borda leste da bacia do Grupo Guaritas, com ocorrências mais escassas na borda oeste (Almeida, 2005). Foram feitas contagens de seixos em dois sítios de amostragem, um situado na borda leste do Grupo Guaritas e outro situado na borda oeste. A leste, próximo ao Alto da Serra das Encantadas, predominam seixos de quartzo milonitos, que compõem $92 \%$ do total, ocorrendo também clastos de granitos miloníticos e metassedimentos (Figura 4). A oeste, próximo ao Alto de Caçapava do Sul, predominam seixos de metassedimentos, compondo $80 \%$ do total, ocorrendo também as classes granitos, riolitos, quartzo milonitos, granitos miloníticos e arenitos (Figura 4).

Os resultados indicam que os depósitos da Formação Pedra das Torrinhas provavelmente sofreram pouco transporte, como é mostrado pela alta angulosidade dos clastos e pela predominância de seixos das unidades localizadas 
nas bordas da bacia, como quartzo milonito a leste, no Alto da Serra das Encantadas, e metassedimentos a oeste, no Alto de Caçapava do Sul.

\section{Formação Serra do Apertado}

Os depósitos da Formação Serra do Apertado são interpretados como de ambiente fluvial dominado por carga de fundo (Almeida, 2005), e nela foram realizadas contagens de seixos em dez sítios de amostragem, sendo que oito estão localizados na região da Serra do Apertado, seção tipo dessa unidade, e outros dois mais a sul, próximos ao Passo do Moinho, correspondentes aos pontos 28 e 29 (Figura 3). A composição dos seixos é tipicamente dominada pelas classes riolito e granito, que variam de 6 a $44 \%$ e 19 a $57 \%$, respectivamente, ocorrendo também quartzo de veio, quartzo milonito, granitos miloníticos, metassedimentos e, em menores proporções, leucogranito, pegmatito, quartzito, aplito e andesito (Figura 4).

Foi realizada a análise multivariada por principais componentes nesta unidade, a fim de avaliar a possível ocorrência de agrupamentos composicionais por classes de seixos. As PC1 e PC2 correspondem, respectivamente, a 60 e 16\% da variância total dos dados e são descritas pelas Equações 4 e 5 :
$\mathrm{PC} 1=-0,213$ and $-0,178 \mathrm{apl}+0,336 \mathrm{arn}+0,262 \mathrm{mts}+$ 0,215 grn mil $+0,318$ grn $-0,025$ leuc $-0,335$ peg $-0,320$ qtzt $+0,315$ qtz veio $+0,341$ qtz mil $+0,224$ rio $+0,336$ sie

PC2 $=0,178$ and $-0,459 a p l+0,009$ arn $-0,029$ mts 0,415 grn mil $+0,121$ grn $+0,681$ leuc $-0,151$ peg $-0,206 q$ tzt $-0,186 q$ tz veio $-0,058$ qtz mil $-0,056$ rio $+0,009$ sie

Onde: and: andesito; apl: aplito; arn: arenito; mts: metassedimentos; grn mil: granito milonítico; grn: granito; leuc: leucogranito; peg: pegmatito; qtzt: quartzito; qtz veio: quartzo de veio; qtz mil: quartzo milonito; rio: riolito; sie: sienito.

O gráfico da Figura 6 mostra o resultado obtido a partir dessa análise estatística multivariada.

Com base no gráfico da Figura 6, é possível observar que ocorrem dois agrupamentos principais internos à Formação Serra do Apertado. O agrupamento que reúne a maior quantidade de pontos de amostragem apresenta valores positivos da primeira componente e possui uma grande variação ao longo do eixo da segunda componente, que se deve a uma variação nas proporções das classes de seixos que ocorrem entre os leucogranitos e os granitos

\section{Formação Serra do Apertado}

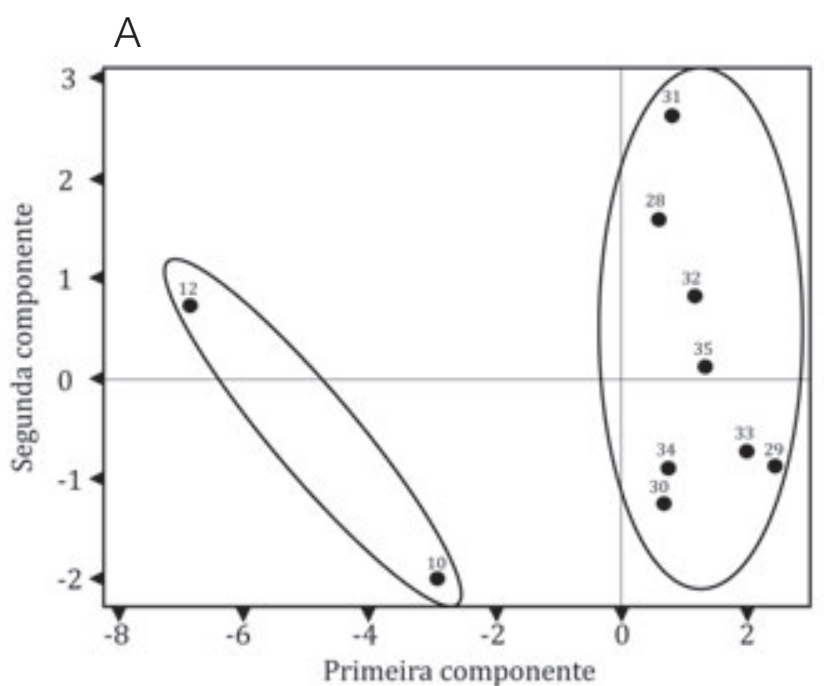

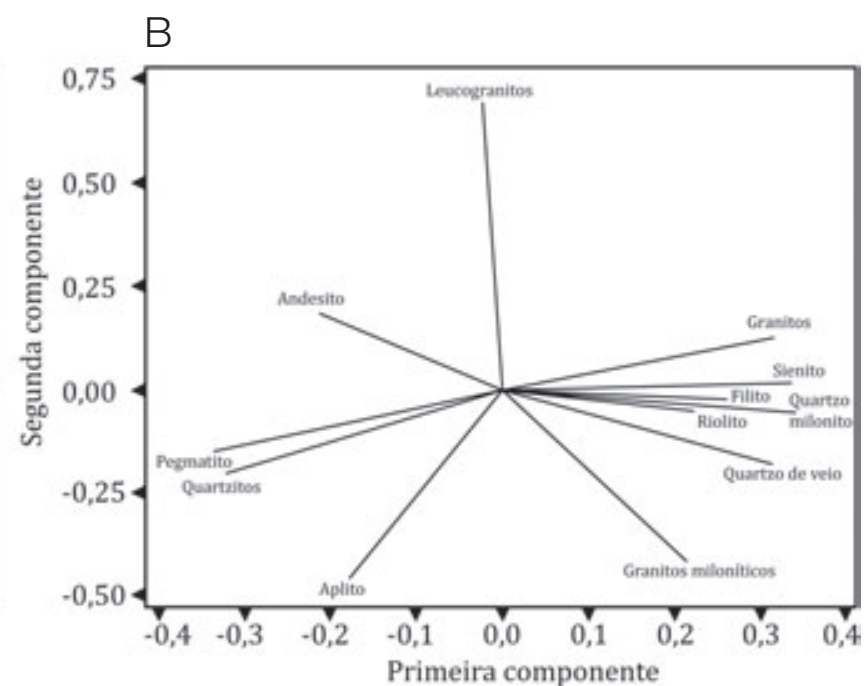

Legendas

- Formação Serra do Apertado

30 Pontos de amostragem

Figura 6. Gráficos de espalhamento (scater plot) (A) e de pesos (loading plot) (B) da análise por principais componentes a partir dos dados composicionais de seixos da Formação Serra do Apertado. Ocorrem dois agrupamentos, um com valores positivos da primeira componente, que abrange a maior quantidade de pontos, e outro com valores negativos da primeira componente. 
miloníticos, como pode ser observado no gráfico de pesos (loading plot) da Figura 6B. O outro agrupamento, que reúne apenas dois pontos de amostragem, correspondentes aos pontos 10 e 12 (Figura 6A), varia entre valores positivos e negativos da segunda componente e apresenta valores negativos da primeira componente, devido à presença de classes de seixos raras, como andesitos, aplitos e quartzitos, que o torna mais polimítico que o outro agrupamento, como pode ser observado no gráfico de pesos (loading plot) da Figura 6B e na Figura 4.

A análise de paleocorrentes nos depósitos da Formação Serra do Apertado, realizada neste trabalho, reuniu, ao todo, 139 medições distribuídas por 6 estações de medidas. As paleocorrentes medidas a partir de estratificações cruzadas acanaladas apresentam uma grande dispersão, mas o vetor médio indica sentido de transporte predominante para noroeste, como pode ser observado no mapa de distribuição das paleocorrentes da Figura 7. A presença de seixos das classes quartzo milonito, granito milonítico e metassedimentos em praticamente todos os sítios onde foram feitas contagens de seixos remetem a uma área fonte situada a leste, corroborando, assim, os dados de paleocorrente obtidos.

Seis dos sítios de amostragem na região da Serra do Apertado encontram-se alinhados perpendicularmente à direção do acamamento local (N27E/8NW), na seção geológica A-A' (Figuras 8 e 9), e compreendem depósitos desde a base da Formação Serra do Apertado, que apresenta contato com a Formação Pedra Pintada sotoposta, até uma porção intermediária da unidade, que, neste local, apresenta espessura mínima de 695 m (Figura 9).

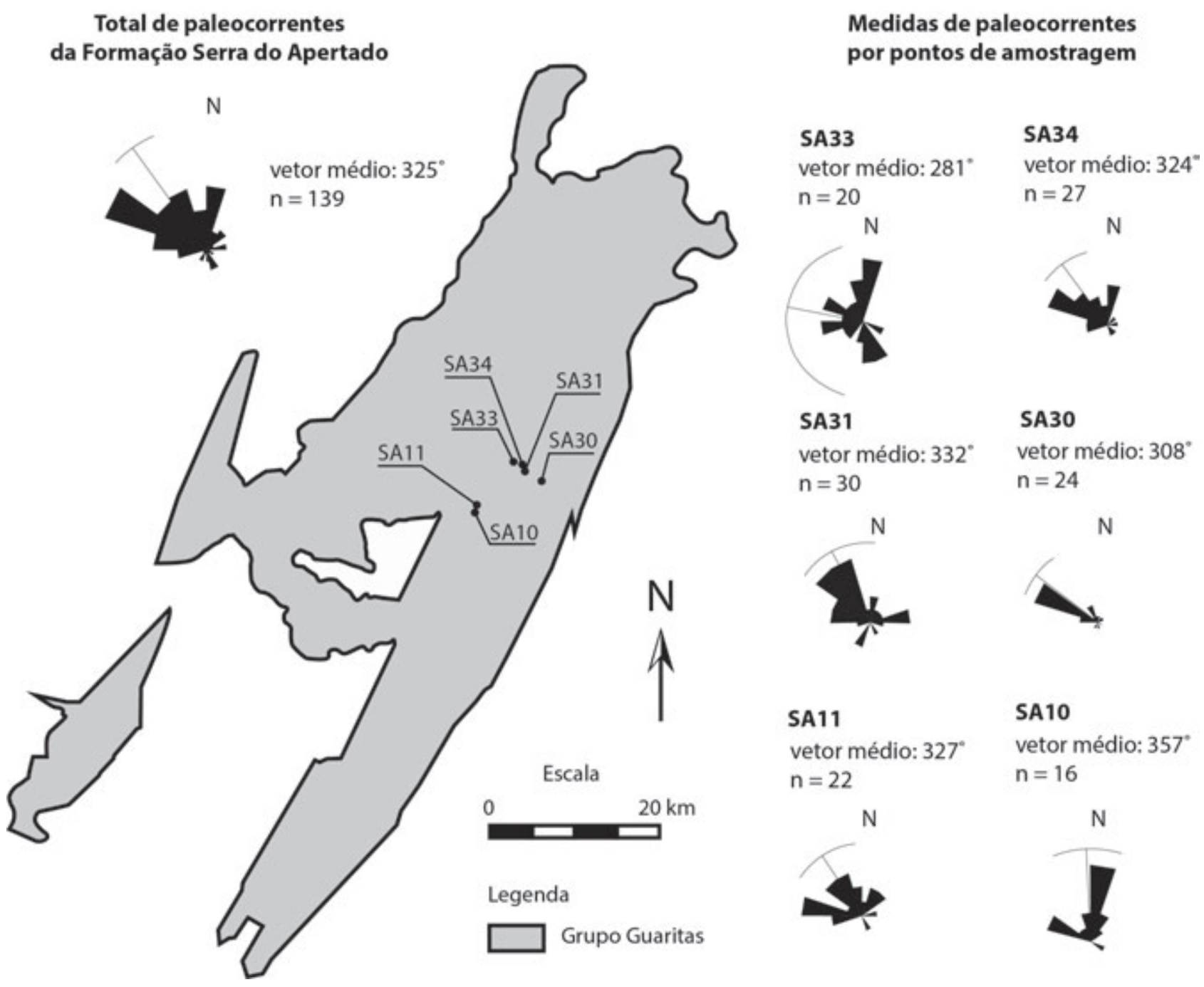

As paleocorrentes foram medidas a partir de estratificações cruzadas acanaladas e laminações cruzadas cavalgantes. Os diagramas em roseta mostram que, em todos os afloramentos analisados, o sentido principal do transporte é para NW ou NNW.

Figura 7. Mapa da distribuição das paleocorrentes da Formação Serra do Apertado na região da serra homônima. 


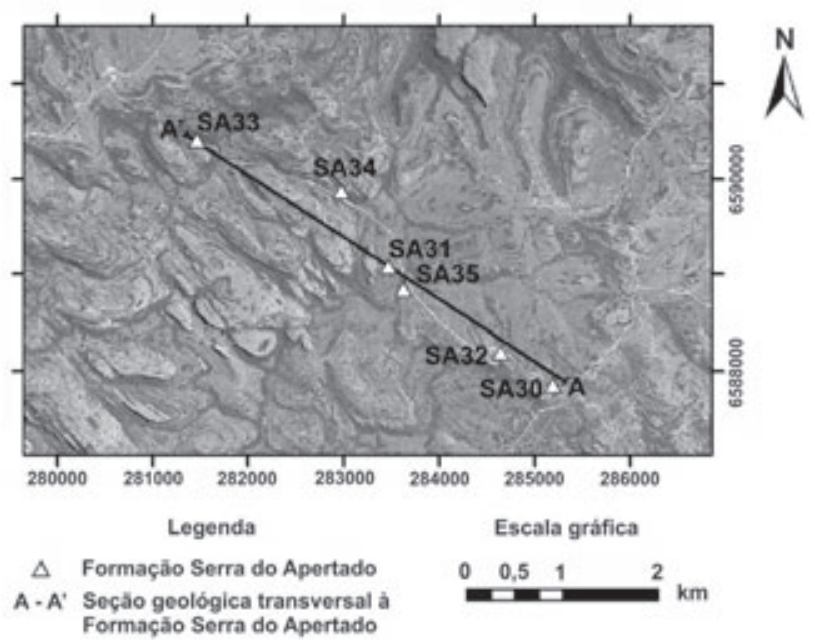

Figura 8. Mapa de pontos da seção geológica A-A'. Na porção W da imagem, situa-se a Serra do Apertado, alinhada segundo a direção NE-SW. É possível observar que os pontos de amostragem encontram-se alinhados perpendicularmente à direção principal da mesma. Imagem de satélite extraída de Google maps.

A Figura 9 mostra que, ao longo da seção geológica A-A', indicada no mapa de pontos da Figura 8, a proporção entre seixos de composição quartzosa e não quartzosa apresenta uma variação vertical significativa. Do ponto SA-30, que está situado na base da Formação Serra do Apertado, até o ponto SA-31, que representa a região estratigraficamente intermediária da seção geológica, a proporção de seixos da classe quartzo de veio decresce gradativamente de 25 para apenas $6 \%$, enquanto a classe quartzo milonito sofre um aumento do ponto SA-30 ao SA-35 de 9 para $21 \%$, mas no ponto SA-31 diminui abruptamente para $9 \%$. As proporções das classes quartzo de veio e quartzo milonito aumentam gradativamente a partir do ponto SA-31 ao ponto SA-33, que representa a porção mais recente dos depósitos na seção, variando de 6 e $9 \%$ para 35 e $24 \%$, respectivamente.

Ainda na Figura 9 é possível observar que, do ponto SA-30 ao SA-31, aumenta gradativamente a proporção da classe granitos, de 27 para $57 \%$, enquanto a classe riolito sofre uma diminuição do ponto SA-30 ao SA-35, variando de 34 a $14 \%$, mas aumenta abruptamente para $22 \%$ no ponto SA-31. No ponto SA-31, ocorre o aparecimento de mais uma classe de seixos não quartzosos, os leucogranitos, com expressão de 5\%. A partir do ponto SA-31, em sentido ao ponto SA-33, ambas as proporções das classes granitos e riolito sofrem uma diminuição gradual, passando de 57 e $22 \%$ para 24 e $6 \%$, respectivamente, e desaparece a classe leucogranitos.

A variação descrita acima mostra que, do ponto SA-30 para o ponto SA-31, a proporção de seixos não quartzosos, como granitos e riolito, sofre um aumento significativo, enquanto a proporção dos seixos quartzosos, como quartzo de veio e quartzo milonito, sofre uma diminuição. Essa tendência se inverte do ponto SA-31 para o SA-33, onde a proporção de seixos não quartzosos diminui gradativamente e aumenta a de seixos quartzosos.

\section{Comparação da proveniência entre as unidades do Grupo Guaritas}

Com base na análise estatística multivariada por principais componentes, foi possível realizar uma comparação entre todas as variáveis de classes de seixos das unidades estratigráficas do Grupo Guaritas, a fim de testar a hipótese preliminar de que as informações providas pela análise de proveniência sedimentar poderiam apontar critérios de descrição das unidades estratigráficas com base na composição dos seixos, podendo, assim, ser utilizadas para auxiliar no reconhecimento e distinção no campo de cada unidade estratigráfica do Grupo Guaritas. As PC1 e PC2 correspondem, respectivamente, a 26 e $17 \%$ da variância total do conjunto de dados e são expressas pelas Equações 6 e 7:

PC1 $=0,118 a$ and $-0,039 a p l+0,125 a r n+0,190 m t s+$ 0,429grn mil-0,473grn-0,117leuc $+0,170$ peg $-0,003$ qtzt $-0,402$ qtz veio $+0,344$ qtz mil $-0,399$ rio $+0,209$ sie

PC2 $=-0,532$ and $+0,421$ apl $-0,199 a r n+0,430 m t s-$ 0,050 grn mil $+0,045$ grn $+0,116$ leuc $-0,052$ peg $-0,477$ qtzt $+0,155$ qtz veio $+0,183$ qtz mil $-0,128$ rio $+0,079$ sie

Onde: and: andesito; apl: aplito; arn: arenito; mts: metassedimentos; grn mil: granito milonítico; grn: granito; leuc: leucogranito; peg: pegmatito; qtzt: quartzito; qtz veio: quartzo de veio; qtz mil: quartzo milonito; rio: riolito; sie: sienito.

O gráfico da Figura 10 mostra o resultado obtido para o teste estatístico supracitado e também que a Formação Guarda Velha é a que apresenta maior variação composicional, com valores predominantemente negativos da primeira componente, que se deve às grandes quantidades de seixos das classes granitos e riolito nessa unidade, com a exceção apenas do ponto 06 , pertencente à região leste da unidade, na Serra das Guaritas, que possui valor positivo devido à presença das classes andesito, quartzo milonito e granitos miloníticos (Figura 10B). A Formação Guarda Velha apresenta grande variação ao longo do eixo da segunda componente, com valores negativos e positivos, que se devem principalmente às variações entre as classes quartzito e metassedimentos (Figura 10B). Essa grande 

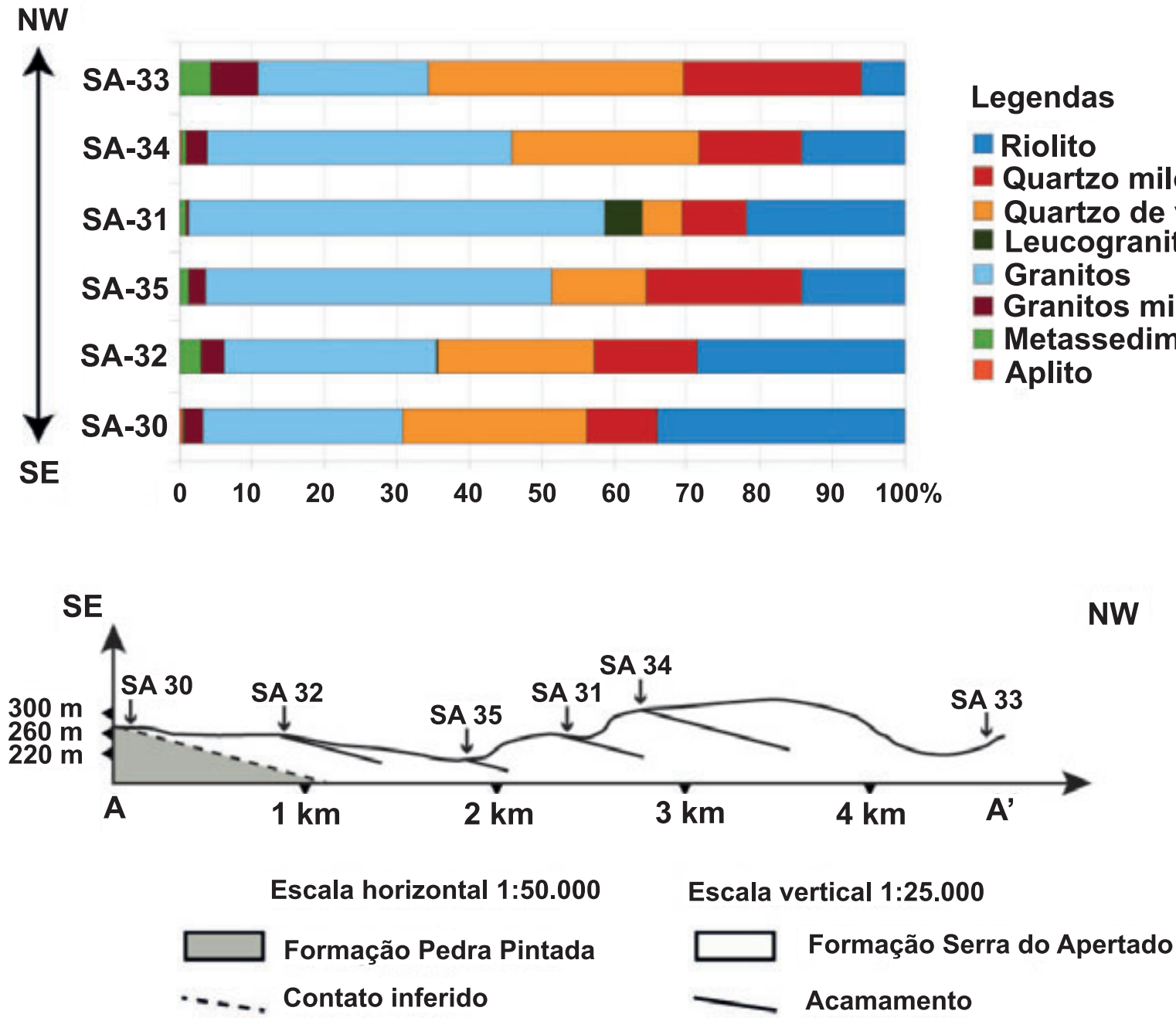

Figura 9. Seção geológica A-A', com exagero vertical de 2x, e gráfico de porcentagem de seixos por sítios de amostragem. Na seção geológica, é possível observar que os sítios de amostragem estão alinhados segundo o rumo de mergulho do acamamento local, de forma que os depósitos tornam-se progressivamente mais recentes para NW. O gráfico de porcentagem em barras mostra a variação na composição dos seixos ao longo da estratigrafia da Formação Serra do Apertado nesse local.

dispersão apresentada pela Formação Guarda Velha pode refletir seus diferentes ambientes deposicionais, com diferentes áreas fonte e processos de transporte. No entanto, outra explicação para a disperção de dados observada seria a maior amostragem realizada nessa unidade, assim como sua maior espessura e área aflorante com relação às demais formações.

A maioria dos pontos de amostragem da Formação Varzinha formam um agrupamento que tende a valores positivos próximos de zero ou negativos da primeira componente, devido à presença de classes de seixos como granitos, riolito e quartzo de veio em sua composição, e positivos da segunda componente, principalmente devido à presença das classes aplito e leucogranito (Figura 10B). Apenas o ponto de amostragem 16 apresenta valores mais positivos da primeira componente e não está inserido no mesmo agrupamento que os demais pontos, pois apresenta proporções mais elevadas de quartzo milonito, granitos miloníticos e metassedimentos, demonstrando uma forte contribuição das áreas proximais situadas a leste, no alto da Serra das Encantadas. Nota-se que o ponto de amostragem 24, pertencente à Formação Varzinha, se assemelha ao ponto 23, pertencente à Formação Guarda Velha, devido à presença da classe de seixos aplito na composição de ambos, como pode ser observado no gráfico de pesos da Figura $10 \mathrm{~B}$ e na Figura 4.

Todos os pontos de amostragem da Formação Pedra Pintada apresentam-se em um mesmo agrupamento, com valores positivos da primeira componente e positivos da segunda componente, o que reflete a grande influência da 


\section{Grupo Guaritas}
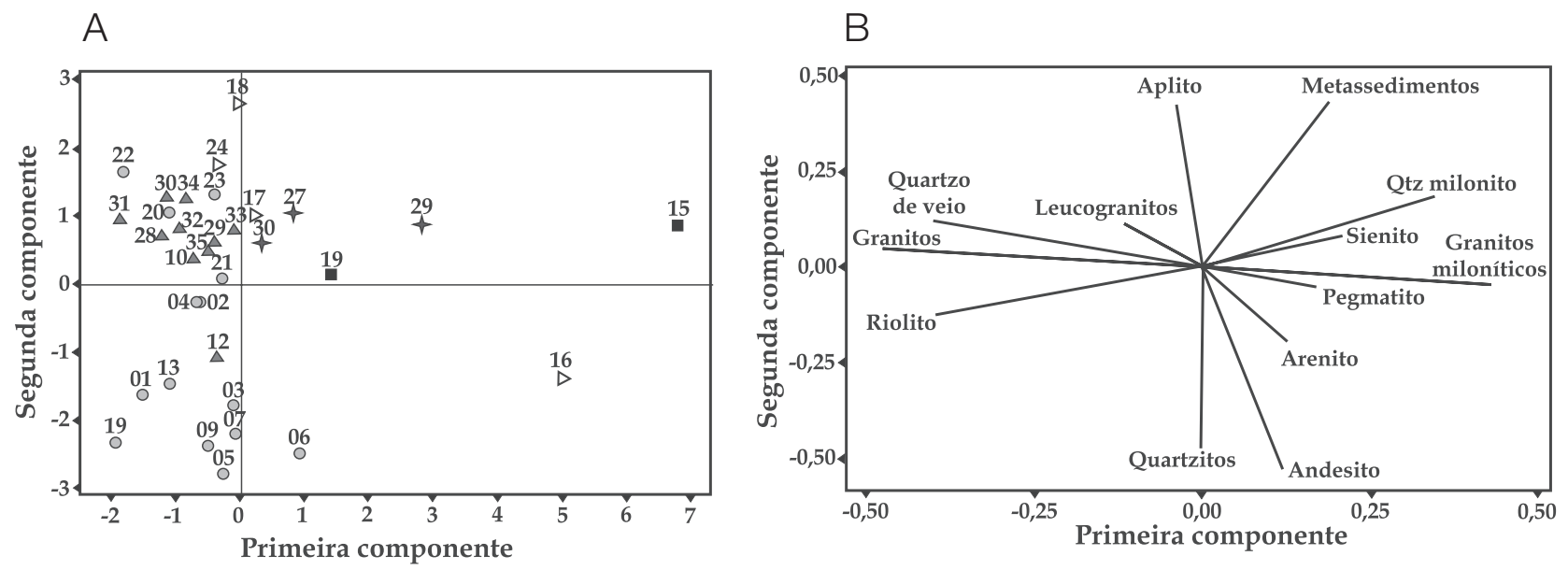

Legenda

$\bigcirc$ Formação Guarda Velha
$\triangleright$ Formação Varzinha $\uparrow$ Formação Pedra Pintada
— Formação Pedra das Torrinhas $\triangle$ Formação Serra do Apertado

16 Pontos de amostragem

Qtz: quartzo.

Figura 10. Gráfico de espalhamento (scater plot) $(\mathrm{A})$ e de pesos (loading plot) $(\mathrm{B})$ da análise estatística por principais componentes dos dados composicionais de seixos de todo o Grupo Guaritas. A legenda mostra os agrupamentos de cada unidade. A grande dispersão dos dados, mesmo dentro de uma mesma unidade, deve-se provavelmente à diversidade de sistemas deposicionais e/ou áreas fonte.

classe quartzo milonito, que é predominante, na composição dos seixos dessa unidade (Figura 10B e Figura 4). Tal assinatura composicional indica uma área fonte muito proximal a leste no alto da Serra das Encantadas.

Na Formação Pedra das Torrinhas, os pontos de amostragem apresentam valores positivos da primeira componente, com uma grande variação ao longo desse eixo, e valores positivos da segunda componente. A grande variação ao longo do eixo da primeira componente é reflexo da presença das classes metassedimentos ou quartzo milonito como tipo de seixo predominante no depósito (Figura 10B e Figura 4), indicando que a unidade possui áreas fonte distintas, situadas nas bordas oeste e leste da bacia do Grupo Guaritas, respectivamente. Vale notar que o ponto 19, pertencente à Formação Pedra das Torrinhas, se assemelha ao ponto 27, pertencente à Formação Pedra Pintada, o que se deve à expressiva proporção de seixos da classe metassedimentos em ambos os pontos de amostragem (Figura 10B e Figura 4).

A maioria dos pontos de amostragem da Formação Serra do Apertado formam um agrupamento principal que apresenta valores negativos da primeira componente, devido à expressiva quantidade das classes granitos, riolito e quartzo de veio na unidade, e valores principalmente positivos da segunda componente, por conta de pequenas contribuições das classes aplito e leucogranito (Figura 10B e Figura 4). O ponto de amostragem 12 destoa dos demais, apresentando valores negativos da segunda componente, o que se deve principalmente à presença da classe quartzitos em sua composição. Vale ressaltar que o ponto 12 assemelha-se muito aos pontos 02 e 03 , pertencentes à Formação Guarda Velha, por também apresentar seixos da classe quartzito em sua composição, além de uma forte influência das classes granitos, riolito e quartzo de veio (Figura 10B e Figura 4).

\section{PALEOGEOGRAFIA E PALEOCLIMA}

Com base nos estudos de proveniência e análise de paleocorrentes realizados no presente trabalho, somados às descrições e análises de paleocorrentes disponíveis na literatura, percebe-se que os depósitos fluviais da região leste das Formações Guarda Velha, Varzinha e Serra do Apertado, assim como os depósitos de interdunas fluviais da Formação Pedra Pintada e os depósitos de leques aluviais da borda leste da Formação Pedra das Torrinhas, possuem sentido de transporte principal para noroeste e áreas fonte situadas a leste, nas regiões da Serra das Encantadas e/ou do Batólito Pelotas. Dessa forma, nos parece plausível supor que, desde o início ao fim da deposição do Grupo Guaritas, houve a contribuição de sedimentos de um mesmo sistema fluvial com área de captação situada nos altos orográficos a leste, com sentido de transporte para noroeste e direção perpendicular ao eixo principal da bacia. 
Desde os depósitos da base da Formação Guarda Velha, ocorrem seixos de quartzo milonitos, metassedimentos e granitos miloníticos, sendo todas essas litologias típicas das rochas que atualmente afloram adjacentes à bacia, no alto da Serra das Encantadas. Somado aos padrões de paleocorrentes da borda leste da unidade, que apontam sentido de transporte predominante para noroeste (Paim, 1995; Almeida, 2005; Santos, 2010), é possível inferir que o alto da Serra das Encantadas já estava instalado na borda leste da bacia desde o princípio da deposição da Formação Guarda Velha. O Batólito Pelotas também já estaria aflorando nesse período, uma vez que seixos de rochas graníticas também estão presentes nos depósitos da base dessa unidade. No entanto, foram observadas variações entre as proporções de seixos característicos de fontes proximais e distais ao longo da estratigrafia do Grupo Guaritas, que podem ser reflexos de mudanças tectônicas e climáticas na borda leste da bacia (Almeida et al., 2009).

Comparando-se os dados de proveniência da porção leste da Formação Guarda Velha com os da porção leste da Formação Varzinha, observa-se que a primeira possui proporções menores das classes de seixos que representam áreas fonte mais proximais, como quartzo milonito e metassedimentos, e proporções maiores de outras classes que representam áreas mais distais, como granitos, quartzo de veio e riolitos. Sendo assim, a proveniência de seixos aponta para uma aparente mudança de área fonte mais distal na Formação Guarda Velha para uma área fonte mais proximal na Formação Varzinha (Figura 11A).

Após a deposição da Formação Varzinha, a proveniência de seixos continua tornando-se cada vez mais proximal, uma vez que a Formação Pedra Pintada é muito mais rica em classes de seixos como quartzo milonitos e metassedimentos, e mais pobre em classes de seixos que representam áreas mais distais, como granitos, leucogranitos e riolitos. Dessa forma, observa-se que, da Formação Guarda Velha para a Formação Pedra Pintada, o sistema fluvial apresenta um aumento gradativo na proporção de seixos provenientes de áreas proximais - o que não seria o esperado em um processo de evolução de relevo normal com erosão remontante - e, consequentemente, contribuições de fontes cada vez mais distais. Uma hipótese que explicaria esse comportamento inverso de evolução da área fonte seria a reativação da falha da borda leste do rift durante a deposição das Formações Varzinha e Pedra Pintada, uma vez que coincidem com a fase de clímax da subsidência mecânica (Almeida, 2005; Almeida et al., 2009), marcada pelos leques aluviais de borda da Formação Pedra das Torrinhas, soerguendo as áreas mais proximais à bacia e obrigando o sistema fluvial a retrabalhá-las (Figuras 11B e 11C).

Os depósitos da Formação Pedra Pintada apresentam maior quantidade de seixos característicos de fontes proximais, como quartzo milonitos, metassedimentos e granitos miloníticos (Figura 4), que ocorrem principalmente na Serra das Encantadas, em comparação com os depósitos da Formação Serra do Apertado, que apresentam mais seixos característicos de fontes distais, como granitos, provenientes do Batólito Pelotas, e quartzo de veio, que indicam maior transporte. Dessa forma, da Formação Pedra Pintada, mais antiga, para a Formação Serra do Apertado, mais nova, é possível observar que as áreas fonte tornamse mais distais, sugerindo que a área de captação do sistema fluvial aumenta sentido a montante (Figura 11D).

Os depósitos das regiões oeste e noroeste das formações Guarda Velha e Varzinha apresentam registros de paleocorrentes com sentido de transporte para sudoeste, que são interpretados como um sistema de rio tronco com direção paralela ao eixo principal da bacia do Grupo Guaritas (Paim, 1995; Almeida, 2005; Santos, 2010). Nos depósitos fluviais da Formação Serra do Apertado, na região da serra homônima, não foram encontradas evidências que apontassem para a existência desse sistema fluvial durante o fim da deposição do Grupo Guaritas. No entanto, como ainda não foram realizadas pesquisas de análises de fácies, de elementos arquitetônicos e de paleocorrentes nos depósitos da região oeste da Formação Serra do Apertado, mais estudos são necessários para averiguar se o sistema de rio tronco identificado nas unidades sotopostas teria ou não coexistido com a deposição de sistemas fluviais transversais na referida formação.

A variação composicional dos seixos observada ao longo da estratigrafia da Formação Serra do Apertado na região da seção A-A', como demonstrado pela Figura 9, não pode ser explicada satisfatoriamente por meio de mudanças na área de captação do sistema fluvial, como ocorreria num processo de erosão remontante ou reativação de uma falha de borda da bacia, que acarretariam no aumento ou diminuição geral dos clastos provenientes de fontes distais, respectivamente, pois, a partir da Figura 9, observa-se que, enquanto a proporção de uma classe de seixos de área fonte distal aumenta, como a dos granitos, por exemplo, a proporção de outra classe de seixos distal, como quartzo de veio, diminui. O mesmo padrão ocorre no caso de classes de seixos proximais, como riolito e quartzo milonito (Figura 9).

Dessa forma, considerando-se a menor suscetibilidade dos seixos quartzosos de sofrerem alterações intempéricas durante o processo de transporte sedimentar em relação aos não quartzosos, interpretamos que as variações composicionais observadas são provavelmente reflexos de mudanças climáticas. Na região da seção geológica A-A' (Figura 9), a maior quantidade de seixos de composição granítica e riolítica é interpretada como resultado de clima mais árido, uma vez que tais litotipos são mais facilmente alteráveis em climas mais úmidos, enquanto a maior quantidade de seixos de composição quartzosa é interpretada como clima mais úmido. Os estudos de análise de elementos arquitetônicos realizados por Godinho et al. (2013) nos depósitos da Formação 


\section{A - Formação Guarda Velha}

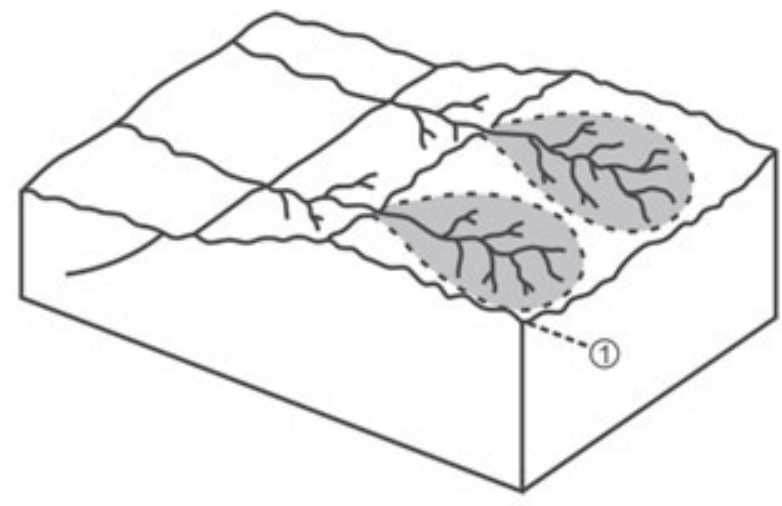

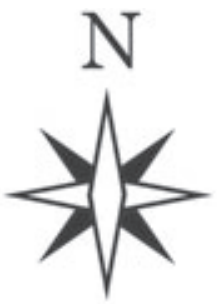

\section{B - Formação Varzinha}

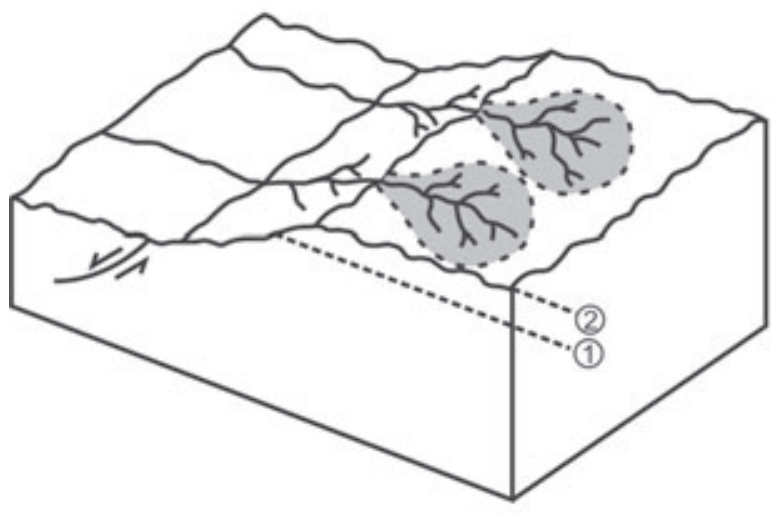

C - Formação Pedra Pintada

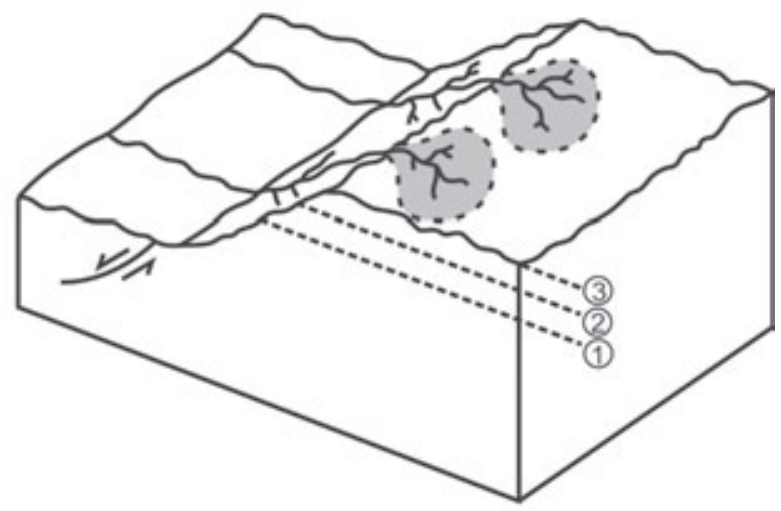

D - Formação Serra do Apertado

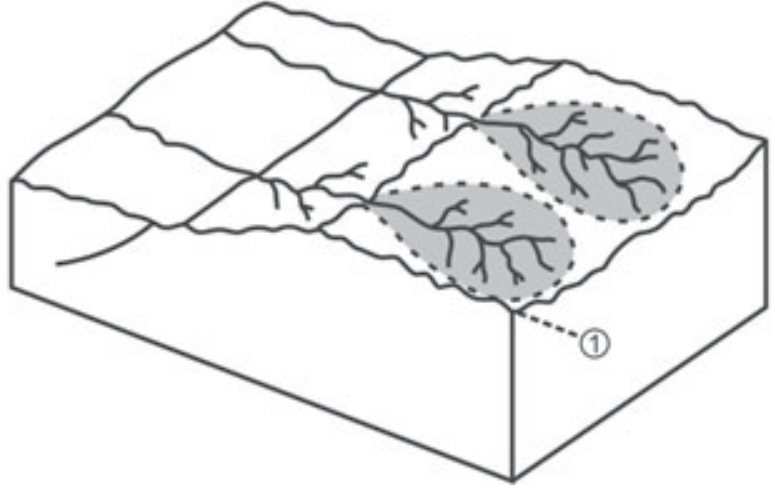

Figura 11. Modelo de evolução paleogeográfica da borda leste da bacia do Grupo Guaritas. As áreas circundadas em cinza representam as principais áreas de captação dos sistemas fluviais transversais. Os números 1, 2 e 3 representam mudanças relativas na altura do bloco soerguido pela falha normal. Todas as dimensões são relativas e não possuem escala. Com base na figura, observa-se que, da Formação Guarda Velha (A) para as Formações Varzinha (B) e Pedra Pintada (C), ocorre um aumento gradual da declividade da escarpa e consecutiva diminuição da área de captação dos sistemas fluviais, devido à reativação da falha de borda da bacia. Entre as Formações Pedra Pintada (C) e Serra do Apertado (D), a reativação da falha é interrompida, e o sistema fluvial torna a avançar sentido a montante, aumentando novamente sua área de captação. 
Serra do Apertado mostram que, na porção intermediária da seção geológica A-A', que corresponde à menor proporção de seixos quartzosos em toda a seção, os depósitos fluviais apresentam variações de vazão mais frequentes do que os demais depósitos da região da Serra do Apertado, corroborando a interpretação da presença de um clima mais árido onde há ocorrência maior de seixos quartzosos.

Vale destacar que as mudanças tectônicas e climáticas acima interpretadas ocorrem em escalas diferentes de tempo. A reativação da falha da borda leste da bacia foi interpretada com base em dados de composição de clastos ao longo de todas as formações do Grupo Guaritas, que, juntas, formam um pacote sedimentar de cerca de $2.000 \mathrm{~m}$ de espessura. Já as variações entre climas mais úmidos e mais áridos na Formação Serra do Apertado encontram-se preservadas em apenas algumas centenas de metros de espessura dessa unidade. Desse modo, observa-se que os estudos de proveniência numa escala mais abrangente, neste caso considerando-se todo o Grupo Guaritas, refletem ciclos temporais mais duradouros, como eventos tectônicos expressivos, enquanto os estudos de detalhe, que neste caso abrangem apenas a Formação Serra do Apertado, evidenciam ciclos temporais relativamente menos duradouros, como variações climáticas.

O diagrama em roseta que expõe o total de paleocorrentes medidas na Formação Serra do Apertado (Figura 7) mostra que o padrão de sentido de transporte se assemelha a de um leque, sugerindo que, ao sair da região dos altos do embasamento e adentrar na bacia sedimentar, os canais do rio se dispersavam lateralmente, mantendo um sentido principal de transporte para noroeste, como já descrito por Paim (1994).

\section{CONCLUSÕES}

O estudo da análise de proveniência de seixos nas unidades do Grupo Guaritas permitiu uma descrição detalhada da composição de seus depósitos, assim como o estabelecimento das relações entre diferentes áreas fonte e ambientes deposicionais distintos.

Na Formação Guarda Velha foi verificado que a ampla variabilidade de composição de seixos, calhaus e matacões é fruto de ambientes deposicionais e tectônicos distintos (Paim, 1995; Almeida, 2005), sendo eles:

- sistema de rio tronco, com áreas fonte distais localizadas a norte, focalizadas no Batólito de Pelotas,

- sistema de rios transversais distributários, com área fonte mais proximal situada no alto da Serra das Encantadas a leste, e

- fase de iniciação do rift, com proveniência mista, de áreas fonte tanto a norte como a leste.

De forma semelhante, na Formação Varzinha, os depósitos na porção central da unidade, que apresentam paleocorrentes com sentido de transporte para SW (Almeida, 2005), possuem classes de litotipos características de fontes mais distais, atribuídas à presença de um sistema de rio tronco com áreas fonte situadas a norte, que também inclui o Batólito Pelotas. Já os depósitos da borda leste, que, por sua vez, apresentam paleocorrentes com sentido para NW, têm composição que indica área fonte situada a leste, no alto da Serra das Encantadas, estando relacionados a um sistema de rios transversais.

Nos depósitos de interdunas fluviais da Formação Pedra Pintada, com sentido de transporte das paleocorrentes para NW (Almeida, 2005), a assinatura da proveniência torna-se muito proximal e característica de áreas fonte a leste. Para a Formação Pedra das Torrinhas, restrita às bordas leste e oeste da Sub-Bacia Camaquã Central, verificaram-se áreas fonte extremamente proximais, localizadas nas adjacências das bordas da bacia.

Os estudos de paleocorrentes realizados no presente trabalho para a Formação Serra do Apertado, juntamente com a análise de proveniência de seixos, mostram que o sentido de transporte predominante nessa unidade se dá para NW, com áreas fonte situadas a leste nas regiões do alto da Serra das Encantadas e do Batólito Pelotas. As contagens de seixos realizadas ao longo de uma seção geológica transversal a Serra do Apertado mostraram variação nas proporções de seixos quartzosos e não quartzosos. Essa variação foi atribuída a mudanças climáticas, sendo que a maior presença de seixos não quartzosos indica regime de clima mais árido, e a maior presença de seixos quartzosos indica clima mais úmido. A seção geológica levantada também confere uma nova espessura mínima de 695 m para a Formação Serra do Apertado, que anteriormente era considerada de $200 \mathrm{~m}$ (Almeida, 2005).

O estudo das áreas fonte dos depósitos da borda leste do Grupo Guaritas, realizado por meio das contagens de clastos, como seixos, calhaus e matacões no presente trabalho, e da compilação dos dados de paleocorrentes de estudos anteriores (Paim, 1995; Almeida, 2005; Santos, 2010), mostrou que todas as unidades do Grupo Guaritas apresentam um sistema fluvial transversal, com área fonte situada a leste e sentido de transporte para noroeste, sugerindo que se tratam do mesmo sistema fluvial que teria existido ao longo de toda a história deposicional preservada da bacia.

A descrição detalhada da composição dos seixos na borda leste do Grupo Guaritas permitiu um estudo de suas variações ao longo da estratigrafia, desde a base até o topo da unidade, permitindo detectar eventos tectônicos que influenciaram na evolução paleogeográfica da bacia. Durante a deposição das formações Varzinha e Pedra Pintada, que coincidem com o estágio de clímax do rift Guaritas (Almeida, 2005), ocorre um aumento gradativo de seixos provenientes de áreas proximais, o que não seria esperado em um processo normal de erosão remontante, no qual deveria ocorrer um aumento gradativo de seixos 
provenientes de áreas cada vez mais distais. O comportamento inverso observado foi interpretado como decorrência da reativação da falha da borda leste da bacia, corroborando as interpretações de Almeida (2005) e Almeida et al. (2009) acerca dos estágios de evolução do rift.

Foi observado que o estudo de proveniência realizado em uma escala mais abrangente, comparando-se todas as unidades do Grupo Guaritas, detectou ciclos de maior duração, como eventos de reativação de falha, enquanto os estudos de detalhe, ao longo de um perfil na Formação Serra do Apertado, evidenciaram ciclos de menor duração, como variações climáticas.

Durante o presente estudo, foi dada maior ênfase à coleta de dados das Formações Guarda Velha e Serra do Apertado, a fim de testar a hipótese de que tais unidades poderiam ser distinguidas com base na composição dos seixos, calhaus e matacões. Foi verificado pelo método estatístico da análise por principais componentes que a maior semelhança entre essas unidades são as altas proporções das classes de seixos granitos, riolito e quartzo de veio, que são dominantemente características de fontes distais. No entanto, não foi verificado que ambas as unidades compartilham o mesmo agrupamento, sendo que a hipótese inicial da distinção entre as formações Guarda Velha e Serra do Apertado pela composição dos seixos foi confirmada.

\section{REFERÊNCIAS}

AITCHISON, J. The Statistical analysis of compositional data. London: Chapman and Hall, 1986. 416 p.

ALMEIDA, F. F. M.; HASUI, Y. O Pré-cambriano do Brasil. São Paulo: Edgard Blücher, 1984. 378 p.

ALMEIDA, R. P. Tectônica e sedimentação do Ediacarano ao Ordoviciano: exemplos do Supergrupo Camaquã (RS) e do Grupo Caacupé (Paraguai Oriental). 2005. 203 f. Tese (Doutorado) - Instituto de Geociências, Universidade de São Paulo, São Paulo.

ALMEIDA, R. P.; JANIKIAN, L.; FRAGOSO-CESAR, A. R. S.; MARCONATO, A. Evolution of a rift basin dominated by subaerial deposits: the Guaritas Rift, Early Cambrian, Southern Brasil. Sedimentary Geology, Amsterdan, v. 217, n. 1-4, p. 30-51, 2009.

BORBA, A. W.; MIZUSAKI, A. M. P.; SILVA, D. R. A.; KAWASHITA, K. Razões isotópicas ${ }^{87} \mathrm{Rb} /{ }^{86} \mathrm{Sr},{ }^{87} \mathrm{Sr} /{ }^{86} \mathrm{Sr}$ e ${ }^{143} \mathrm{Nd} /{ }^{144} \mathrm{Nd}$ como traçadores de proveniência de rochas sedimentares siliciclásticas: exemplos no Grupo Camaquã (Paleozóico inferior, RS, Brasil). Pesquisas em Geociências, Porto Alegre, v. 30, n. 2, p. 39-50, 2003.

DAVIES, N. S.; GIBLING, M. R. Cambrian to Devonian evolution of alluvial systems: The sedimentological impact of the earliest land plants. Earth-Science Reviews, v. 98, n. 3-4, p. 171-200, 2010.

DAVIS, J. C. Statistics and Data Analysis in Geology. New York: Wiley \& Sons, 1986. 646 p.

DE ROS, L. F.; MORAD, S.; PAIM, P. S. G. The role of detrital composition and climate on the diagenetic evolution of continental molasses: evidences from the CambroOrdovician Guaritas Sequence, southern Brazil. Sedimentary Geology, Amsterdam, v. 92, n. 3-4, p. 197-228, 1994.

DÜRR, S. B. Quick estimation of pebble volumes. Journal of Sedimentary Research, Lawrence, Kansas, v. 64, n. 3A, p. 677-679, 1994.

DÜRR, S. B. Provenance of the Xigaze fore-arc basin clastic rocks. Geological Society of America Bulletin, Boulder, Colorado, v. 108, n. 6, p. 669-684, 1996.

EMPRESA BRASILEIRA DE PESQUISA AGROPECUÁRIA. SH-22-Y-A. Disponível em: http:// www.relevobr.cnpm.embrapa.br/download/index.htm. Acesso em Agosto de 2010.

FRAGOSO-CESAR, A. R. S. Tectônica de placas no Ciclo Brasiliano: as orogenias dos Cinturões Dom Feliciano e Ribeira no Rio Grande do Sul. 1991. 366 f. Tese (Doutorado) - Instituto de Geociências, Universidade de São Paulo, São Paulo.

FRAGOSO-CESAR, A. R. S.; FAMBRINI, G. L.; ALMEIDA, R. P.; PELOSI, A. P. M. R.; JANIKIAN, L.; RICCOMINI, C.; MACHADO, R.; NOGUEIRA, A. C. R.; SAES, G. S. The Camaquã extensional basin: Neoproterozoic to Early Cambrian sequences in southernmost Brazil. Revista Brasileira de Geociências, São Paulo, v. 30, n. 3, p. 442-445, 2000.

FRAGOSO-CESAR, A. R. S; PAES-DE-ALMEIDA, R.; FAMBRINI, G. L.; PELOSI, A. P. M. R.; JANIKIAN, L. A Bacia Camaquã: um sistema intracontinental anorogênico de rifts do Neoproterozóico III Eopaleozóico no Rio Grande do Sul. In: Encontro sobre Estratigrafia do Rio Grande do Sul: Escudos e Bacias, 1., 2003. Porto Alegre. Anais... Porto Alegre: LÉO A. HARTMANN, 2003. p. 139-144.

GODINHO, L. P. S.; ALMEIDA, R. P.; SANTOS, M. G. M.; MARCONATO, A.; FRAGOSO-CESAR, A. R. S. Fácies sedimentares e elementos arquitetônicos das formações Serra do Apertado e Pedra Pintada na região das Minas do Camaquã - RS. Geologia USP: Série Científica, v. 13, n. 2, p. 29-48, 2013. 
GRAHAM, S. A.; TOLSON, R. B.; DECELLES, P. G.; INGERSOLL, R. V.; BARGAR, E.; CALDWELL, M.; CAVAZZA, W.; EDWARDS, D. P.; FOLLO, M. F.; HANDSCHY, J. F.; LEMKE, L.; MOXON, I.; RICE, R.; SMITH, G.A.; WHITE, J. Provenance modelling as a technique for analysing source terrane evolution and controls on foreland sedimentation. In: ALLEN, P. A.; HOMEWOOD, P. (eds.). Foreland Basins: Special Publication of the International Association of Sedimentologists, n. 8. Oxford, London, 1986.

HARTMAN, L. A.; SANTOS, J. O. S.; MCNAUGHTON, N. J. Detrital zircon U-Pb age data, and Precambrian provenance of the Paleozoic Guaritas Formation, Southern Brazilian Shield. International Geology Review, Columbia, Maryland, v. 50, n. 4, p. 364-374, 2008.

HASUI, Y.; CARNEIRO, C. D. R.; COIMBRA, A. M. The Ribeira Folded Belt. Revista Brasileira de Geociências, São Paulo, v. 5, p. 257-266, 1975.

JANIKIAN, L.; ALMEIDA, R. P.; TRINDADE, R. I. F.; FRAGOSO-CESAR, A. R. S.; D'AGRELLA-FILHO, M. S.; DANTAS, E. L.; TOHVER, E. The continental record of Ediacaran volcano-sedimentary successions in southern Brazil and their global implications. Terra Nova, Cowley, Oxford, v. 20, n. 4, p. 259-266, 2008.

JONES, A. P. Late quaternary sediment sources, storage and transfers within mountain basins using clast lithological analysis: Pineta Basin, central Pyrenees, Spain. Geomorphology, Amsterdan, v. 34, n. 3-4, p. 145-161, 2000.

Long, D. G. F. Architecture of pre-vegetation sandy-braided perennial and ephemeral river deposits in the Paleoproterozoic Athabasca Group, northern Saskatchewan, Canada as indicators of Precambrian fluvial style. Sedimentary Geology, v. 190, n. 1-4, p. 71-95, 2006.

MARCONATO, A.; ALMEIDA, R. P.; SANTOS, M. G. M; NÓBREGA, J. E. S.; SOUZA, R. B. Alluvial-eolian interaction in a Cambrian rift margin: the Pedra das Torrinhas and Pedra Pintada formations (Guaritas Group, RS). Anais da Academia Brasileira de Ciências, Rio de Janeiro, v. 81, n. 4, p. 819-836, 2009.

MARCONATO, A. A influência da evolução de altos estruturais em sucessões aluviais: exemplos do Ediacarano e do Cambriano da Bacia Camaquã (RS). 2010.74f. Dissertação (Mestrado) - Instituto de Geociências, Universidade de São Paulo, São Paulo.

NÓBREGA, J. E. S.; SAWAKUCHI, A. O.; ALMEIDA, R. P. Minerais pesados das porções média e superior do Grupo Guaritas (Eocambriano, RS): considerações sobre a proveniência sedimentar. Revista Brasileira de Geociências, v. 38, n. 3, p. $554-565,2008$.

NÓBREGA, J. E. S. Proveniência sedimentar do Grupo Guaritas, Cambriano da Bacia do Camaquã (RS). 2011. 47 f. Dissertação (Mestrado) - Instituto de Geociências, Universidade de São Paulo, São Paulo.

PAIM, P. S. G. Depositional systems and paleogeographical evolution of the Camaquã and Santa Barbara Basins, Brazil. 1994. 277 f. Doctor Thesis, University of Oxford.

PAIM, P. S. G. Alluvial palaeogeography of the Guaritas depositional sequence of southern Brazil. In: PLINT, A. G.; READING, H. G. Sedimentary fácies analysis: a tribute to the research and teaching of Harold G. Reading. Special Publication of International Association of Sedimentology, n. 22. Oxford: Blackwell Science, 1995. p. 3-16.

PAIM, P. S. G.; SCHERER, C. M. S. High-resolution stratigraphy and depositional model of wind- and waterlaid deposits in the ordovician Guaritas rift (Southernmost Brazil). Sedimentary Geology, Amsterdam, v. 202, n. 4, p. 776-795, 2007.

PAWLOWSKY-GLAHN, V.; EGOZCUE, J. J. Compositional data and their analysis: an introduction. In: BUCCIANTI, A.; MATEU-FIGUERAS, G.; PALOWSKYGLAHN, V. (eds). Compositional Data Analysis in the Geosciences: From Theory to Practice. London: Geological Society, Special Publications, v. 264, p. 1-10, 2006.

RIBEIRO, M.; BOCCHI, P. R.; FIGUEIREDO FILHO, P. M.; TESSARI, R. I. Geologia da quadrícula de Caçapava do Sul. Rio de Janeiro: DNPM/DFPM, 1966. 232 p. (Boletim 127).

ROBERTSON, J. F. Revision of stratigraphy and nomenclature of rock units in Caçapava-Lavras region. Notas e estudos, Porto Alegre, IG-UFRGS, v. 1, n. 2, p. 41-54, 1966.

SANTOS, M. G. M. Tectônica e sedimentação na Bacia do Camaquã Central (RS): exemplos do Grupo Guaritas e do Grupo Santa Bárbara. 2010. 117 f. Dissertação (Mestrado) - Instituto de Geociências, Universidade de São Paulo, São Paulo.

TIRSGAARD, H.; ØXNEVAD, I. E. I. Preservation of pre-vegetational mixed fluvio-aeolian deposits in a humid climatic setting: an example from the Middle Proterozoic Eriksfjord Formation, Southwest Greenland. Sedimentary Geology, Amsterdam, v. 120, n. 1, p. 295-317, 1998.

WELTJE, G. J.; VON EYNATTEN, H. Quantitative provenance analysis of sediments: review and outlook. Sedimentary Geology, Amsterdam, v. 171, n. 1-4, p. 1-11, 2004. 